\title{
Edible Coating and Pulsed Light to Increase the Shelf Life of Food Products
}

\author{
Annachiara Pirozzi ${ }^{1} \cdot$ Gianpiero Pataro $^{1} \cdot$ Francesco Donsi $^{1}$ (D) $\cdot$ Giovanna Ferrari ${ }^{1,2}$
}

Received: 22 May 2020 / Accepted: 31 July 2020 / Published online: 24 August 2020

(C) The Author(s) 2020

\begin{abstract}
The application of edible coatings (EC) in combination with pulsed light (PL) treatments represents an emerging approach for extending the shelf life of highly perishable but high value-added products, such as fresh-cut fruits and vegetables. The surface of these products would benefit from the protective effects of ECs and the PL decontamination capability. This review describes in detail the fundamentals of both EC and PL, focusing on the food engineering principles in the formulation and application of EC and the delivery of efficient PL treatments and the technological aspects related to the food characterization following these treatments and discussing the implementation of the two technologies, individually or in combination. The advantages of the combination of EC and PL are extensively discussed emphasizing the potential benefits that may be derived from their combination when preserving perishable foods. The downsides of combining EC and PL are also presented, with specific reference to the potential EC degradation when exposed to PL treatments and the screening effect of PL transmittance through the coating layer. Finally, the potential applications of the combined treatments to food products are highlighted, comparatively presenting the treatment conditions and the product shelf-life improvement.
\end{abstract}

Keywords Edible coatings $\cdot$ Pulsed light $\cdot$ Combined treatments $\cdot$ Food preservation $\cdot$ Shelf-life extension $\cdot$ Nonthermal technologies

\section{Introduction}

Mild preservation techniques have, nowadays, gathered a key role in many food productions. They are frequently used in replacement of heat treatments, to preserve the food nutritional and sensory properties, while ensuring microbial safety and a prolonged product shelf life [1]. In the case of products where heat treatments are not suitable, such as fresh or fresh-cut fruits and vegetables, or raw or cured meat and fish products, mild preservation techniques are chosen to avoid the use of synthetic preservatives, such as sulfites, benzoic acid, or its derivative salt, which are increasingly rejected by

Gianpiero Pataro gpataro@unisa.it

Francesco Donsì fdonsi@unisa.it

1 Department of Industrial Engineering, University of Salerno, via Giovanni Paolo II, 132, 84084 Fisciano, SA, Italy

2 ProdAl scarl, University of Salerno, via Giovanni Paolo II, 132, 84084 Fisciano, SA, Italy consumers [2], and often represent the only option for widerange distribution if the use of chemical preservatives is not allowed by food authorities [3, 4]. They can also be applied to contribute to improving the shelf life for enhanced distribution of perishable products or to compensate for logistics characterized by inefficient structures or inadequate cold chain in rural areas.

One possible, relatively simple approach, is represented by edible coatings (EC) [2]. Differently from edible films, which are first formed and then applied as a wrapping on the food product, ECs are applied in liquid form directly on the surface of the food to be coated, to exert a protective action against mechanical damage and chemical reaction, and to act as a moisture barrier. They also represent a physical barrier to microbiological attack. ECs have been traditionally used in food conservation, such as in the case of wax coatings for fruit, used since the twelfth century, chocolate coatings for confectionery, or lipid films for meat products [5]. In their modern version, ECs are applied as a very thin layer to minimally affect product appearance, to protect food products from deterioration processes, including oxidation, moisture absorption/desorption, chemical reactions, and microbial growth, as well as to improve their physical strength, reduce particle 
clustering, and possibly improve visual and tactile properties of food product surfaces [5]. These functions are mainly based on their capability to act as barriers against water or oil permeation and gas or vapor transmission [6]. Moreover, ECs can also be loaded with active ingredients, to integrate or develop properties that can aid in extending the shelf life, such as antimicrobial, anti-browning, antioxidant, coloring, and flavoring agents and even nutrients [2]. In particular, active coatings with antimicrobial properties are especially appealing, because they can be formulated with natural ingredients, and, in addition to the above-mentioned physical barrier properties, ECs also enable controlled release of natural antimicrobials [7-10].

The use of ECs in combination with other preservation technologies presents significant potential benefits to food preservation, within the hurdle technology approach, to attain mild but reliable preservation effects $[3,11]$. The ECs have been tested in combination with different nonthermal technologies, such as high hydrostatic pressure, pulsed light [8], $\gamma$ radiation, ozone, UV light [9], and modified atmosphere packaging [12]. In some cases, synergistic effects (e.g., in combination with $\gamma$-radiation and modified atmosphere packaging [12] or high hydrostatic pressure [8]), in other cases, a simply additive effect (e.g., in combination with UV light [9]) or antagonistic effects (e.g., in combination with ozone [9] and pulsed light [8]) were observed on microbial stabilization. Pulsed light (PL) represents an extremely promising technology for the surface decontamination of food products [13], because of the microbial inactivation effect achieved by PL through structural damages caused by photophysical and photothermal effects, as well as the damage of the microorganism DNA, among others [14]. Therefore, PL has a recognized potential to be widely adopted in the food industry, as recently reviewed [13]. It is specifically suitable to be applied in combination with the application of ECs, to further contribute to extending the shelf life of high value-added food products, either by avoiding contamination after EC deposition, also through in-package treatments, or as a strategy to attain a fast initial reduction of the microbial load before the coating process.

This review describes the combined use of edible coatings and pulsed light treatments. It illustrates the key issues in the formulation of coating solutions and their deposition on food products, the addition of active ingredients to expand their functionalities, and the characterization methods, also as a function of the existing food applications. It also addresses the main technical aspects related to PL treatments, especially as a function of the target preservation process. Finally, it presents a critical analysis of the combination of ECs and PL treatments, discussing the possible process configurations and the interferences between the two technologies and surveying the existing literature on the topic.

\section{Edible Coatings}

\section{Materials}

\section{Coating Materials}

ECs can be fabricated with different materials, which can be classified into three categories: hydrocolloids, including polysaccharides and proteins; lipids; and composite materials, consisting of a combination of different hydrocolloids or hydrocolloids and lipids, to exploit the complementary functional properties of the different constitutive materials or overcome the respective drawbacks $[5,15,16]$. Table 1 reports a survey of the main film-forming materials, with the indication of the solvents needed for their application, and the main advantages and disadvantages of the ECs obtained with such materials. The selection of the coating materials and their additives is generally based not only on the desired technological properties, but also on market availability, cost-effectiveness, effects on the sensory attributes of the final product, and consumer acceptance [77, 78]. It is required that for market applications, the coating materials are generally regarded as safe (GRAS) and approved by regulatory agencies, such as the US Food and Drug Administration (US FDA), through the inclusion in the Code of Federal Regulations (CFR) - Title 21, or the European Food Safety Authority (EFSA), through the inclusion in the Food Additives database of the European Commission [79].

Notably, polysaccharide-based coatings include many water-soluble polymers, which are easy to prepare and deposit on food products, and usually are cost-effective $[80,81]$. Generally, very hydrophilic polysaccharide coatings do not provide good water vapor barrier properties [82], but they exhibit selective permeability for $\mathrm{O}_{2}$ and $\mathrm{CO}_{2}$ and resist lipid migration [81, 83]. Among polysaccharide-based materials, alginates have been widely used in different products because of their properties and regulatory status [25-31]. Chitosan has also been intensively investigated because of its intrinsic antimicrobial activity [84] and because its properties can be further improved by chemical modification [9] or blending with other polymers. Many native and modified starches from plant sources have been used in the formulation of ECs because they exhibit very good encapsulation, film-making, and emulsification properties. However, their application as ECs is limited by their poor mechanical strength and barrier properties [85]. Most protein-based ECs show good hydrophilic but poor moisture barrier properties.

The application of lipids as ECs has not been favored, because they often exhibit microscopic pores, high $\mathrm{O}_{2}$ solubility, and diffusivity, and cause undesirable organoleptic properties [86]. The combination of hydrocolloids and lipids could improve the structural integrity and characteristic functionality of the EC, as polysaccharide and proteins exhibit 


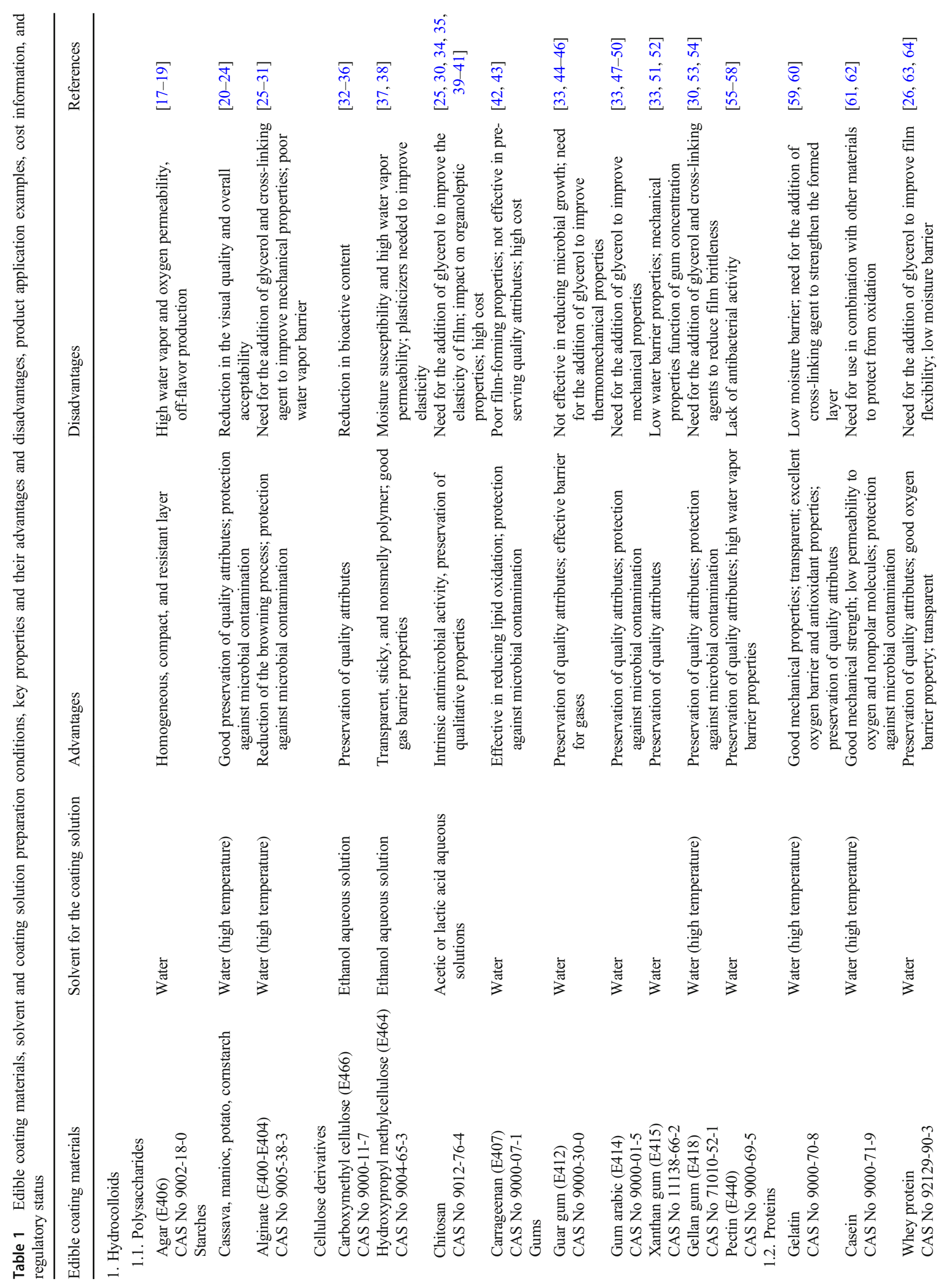




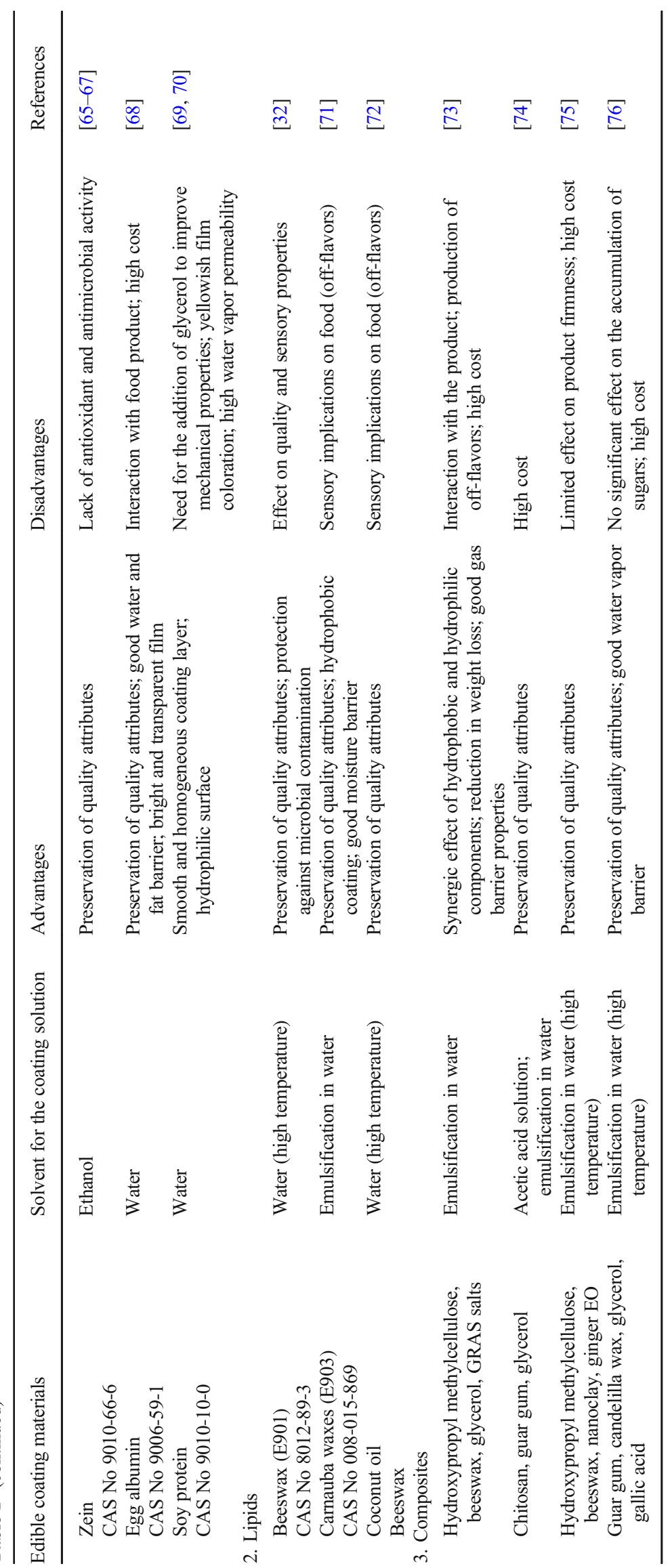


poor moisture barrier properties, whereas lipids exhibit poor gas barrier properties.

\section{Cross-linking Agents}

Cross-linking by covalent and noncovalent bonds [87] of the coating polymers chains, particularly proteins and polysaccharides, can be achieved by the application of a crosslinking agent after depositing the polymer coating solution on the food surface, to form a more compact and resistant layer [88, 89] and to improve mechanical strength, chemical resistance, and thermal stability [90]. The most common cross-linking agents are symmetrical bifunctional compounds with reactive groups with specificity for functional groups present on the matrix polymer [91]. The most common cross-linking agents include glutaraldehyde for gelatin, cellulosic derivatives, and chitosan [92-95]; $\mathrm{Ca}^{2+}$ ions for alginate, pectin, and whey proteins [96-99]; citric acid for starch and cellulose derivatives [100-103]; and tannic acid for gelatin and chitosan [104, 105].

\section{Plasticizers}

Plasticizers are additives rich in hydroxyl groups that contribute to preventing cracking during handling and storage, through the plasticization of the polymer network. The primary objectives of plasticizer addition include increasing the free volume or molecular mobility of biopolymers, decreasing intermolecular attractions between adjacent polymeric chains by reducing hydrogen bonding between polymers chains, bestowing flexibility, reducing brittleness, improving tear impact resistance, and regulating the flow of the coating material [106-111]. The most commonly used plasticizers are polyols (propylene glycol, glycerol, sorbitol, polyethylene glycol), oligosaccharides (glucose, fructose, and sucrose), and water (known as an excellent plasticizer [112]). Glycerol is particularly suitable and often used in hydrocolloid-based coatings [113, 114].

\section{Surfactants}

Adhesion of hydrophilic ECs on hydrophobic food surface is inherently poor because the different chemical nature of the two surfaces makes it difficult to obtain a uniform EC [16, 115]. Surface active agents, such as surfactants, are frequently added into coating formulations to improve surface adhesion of hydrophilic coatings on hydrophobic surfaces, and vice versa, increasing the wettability of the product [116-118]. A widely used natural surfactant in EC is lecithin, which is GRAS and exhibits a high efficiency as an emulsion stabilizing agent [119]. Other common surfactants are lecithin derivatives, acetylated monoglyceride, ethylene glycol monostearate, glycerol monostearate, and sorbitan fatty acid esters (Tweens), which are all GRAS [120].

\section{Antimicrobial, Antioxidant, and Anti-browning Additives}

ECs can be loaded with different bioactive compounds of natural origin to promote specific functionalities, such as antimicrobial, antioxidant, and anti-browning activities, by retarding deterioration, rancidity, or discoloration due to oxidation caused by free radicals and reducing the extent of enzymatic and nonenzymatic oxidation of phenolic compounds [121-125]. The organoleptic properties of the coated products can also be improved if the coating is loaded with flavoring or coloring agents, as well as with sweeteners, spices, and seasonings $[82,111,126]$.

Essential Oils Essential oils (EOs), which consist of a mixture of esters, aldehydes, ketones, terpenes, and phenolic compounds, found in aerial or underground parts of plants [127], are gathering an increasing interest because, in addition to their well-documented health-beneficial properties [128, 129], they exhibit a strong nonspecific antimicrobial action [130]. Because of their low solubility in water, EOs need to be delivered through suitable carriers, such as nanoemulsions or other colloidal particles $[127,131]$. In the case of ECs, the biopolymer solution might contain macromolecules with an interfacial activity, which is sufficient to stabilize a fine dispersion of EOs; however, in most cases, an additional emulsifier and an adequate emulsification process are required to obtain a coating with homogeneously dispersed EOs [132-134]. However, some authors have reported that the incorporation of essential oils in EC might impart undesirable sensorial modifications in foods [128, 135].

Plant Extracts Different plant extracts may exhibit a significant antimicrobial activity, associated to their high content in polyphenols [136], as well as antioxidant and antimutagenic properties, and to inhibit lipid oxidation in food [137]. For example, Aloe vera gel, because of its high content in antiseptic compounds, as well as in polysaccharides, has attracted increasing interest in the preparation of active coatings [138-141]. Several other plant extracts have been tested as additives to coating formulations for their antimicrobial activity, such as Tartary buckwheat extracts [142] or olive leaf extracts [143]. A sustainable source of antimicrobial bioactive compounds is represented by agri-food residues, which are increasingly exploited, such as the ethanolic extracts of the leaves and pods of cocoa, the leaves and hulls of coffee [144], or the grape seed extracts [39]. Similar to EOs, the addition of natural extracts to EC may impart a bitter taste and astringent or off-flavor, impairing the acceptability of the product $[135,145]$. 
Extracts from Algae and Mushrooms Algae and mushrooms are naturally rich in bioactive compounds, with significant antimicrobial, antioxidant, antiviral, and anti-inflammatory activities [137], such as proteins, antioxidant molecules (e.g., polyphenols, flavonoids, and carotenoids), polyunsaturated fatty acids, and polysaccharides [146]. For example, for the preparation of ECs for strawberries, both Palmaria palmata seaweed extracts, in combination with chitosan [147], and fucoidan recovered from Laminaria japonica alga [148] were tested.

Animal-Derived Compounds Another important class of natural antimicrobial compounds is represented by those derived from animal sources. Chitosan is a polycation biopolymer, naturally present in the exoskeletons of arthropods and crustaceans [149], which has attracted significant interest because of its biodegradability, biocompatibility, bioadhesion, and nontoxicity [150]. Because of its film-forming properties and intrinsic antimicrobial activity, it is highly effective in extending the shelf life of food products, retarding oxygen, moisture, solute transports, and aromas [151]. It must be remarked that chitosan can be obtained also from fungal sources [152] and chitin through diatom photobioreactors $[153,154]$.

Lysozyme is an enzyme naturally found in mammalian milk and poultry eggs [155], which is usually considered safe to be added directly to food [137]. Its combination with compounds capable of destabilizing the outer membrane of Gram-negative bacteria, such as nisin, EDTA, or EOs, significantly increases the spectrum of its antimicrobial activity [137]. Lactoferrin is a whey glycoprotein, which can bind one or two ferric ions $\left(\mathrm{Fe}^{2+}\right.$ or $\left.\mathrm{Fe}^{3+}\right)$, whose antimicrobial activity is reported to cause outer membrane damages to microbial cells [156]. Lactoperoxidase, found in high concentrations in bovine milk [157], exhibits antimicrobial activity mainly against Gram-negative bacteria and is frequently used in combination with chitosan in ECs [158].

Microbial-Derived Compounds A variety of compounds of microbial derivation exhibit a significant antimicrobial activity. Nisin is a bacteriocin (antimicrobial peptide) produced by lactic acid bacteria (Lactococcus lactis subsp. lactis) [137], which is a GRAS food preservative, approved for commercial products [159], because of its antimicrobial activity against Gram-positive bacteria [160]. Lacticin is a two-peptide bacteriocin, also produced by L. lactis subsp. lactis, but with a stronger activity and higher target specificity against Grampositive bacteria than nisin [161]. Pediocins, produced by Pediococcus species, are small, cationic proteins with antilisterial activity and antimicrobial effect against Grampositive bacteria, which are reported to maintain their antimicrobial activity over a wide range of $\mathrm{pH}$ values and temperature range [162]. Reuterin is a D-ribose analog generated by Lactobacillus reuteri during glycerol metabolism. It has a recognized antibacterial activity against food-borne pathogens and spoilage bacteria, with higher activity against Gram-negative bacteria than Gram-positive bacteria [163].

Organic acids, such as acetic, ascorbic, citric, and lactic acid, are organic compounds, all characterized by one or more carboxyl groups $(-\mathrm{COOH})$ in their structure, and in addition to being GRAS, they are known to possess antimicrobial properties of interest for food application [137].

\section{Applications of Edible Coatings to Food Products}

A survey of the recent scientific literature on the application of ECs for the preservation of different products, summarized in Table 2, includes their effect on shelf-life extension. In general, product applications have focused on the treatment of products characterized by high added value, short shelf life, or difficult logistics associated with production in remote or rural areas. As a recent trend, it must be remarked that natural coating materials are increasingly attracting the interest of researchers, as shown by the wide use of Aloe vera gel [138-141] and other natural polysaccharides, such as chitosan $[9,12,25,39,74,142,147,152,164-166,168-170,172$, $174,179,180,186,190,193,201]$, or seaweed extracts [148], which exhibit an intrinsic antimicrobial activity, significantly contributing to extending the product shelf life. The tendency toward natural products is also confirmed by the wide use of natural gums [47, 181], starches [20, 188, 195], cellulose, and its derivatives [32, 167, 173, 175, 194], and other compounds recovered from agri-food residues [144, $183,203]$. Glycerol is frequently used as a plasticizer, at concentrations ranging from less than 1 to $20 \%$. Another trend that became evident in recent years is the addition of natural extracts as antimicrobial or antioxidant agents, including essential oils $[9,12,29,172,177-179,181,185,186,188,192$, $193,195,198,202]$ and different plant and fruit extracts [39, 48, 142, 144, 164, 167, 174, 182, 184, 187, 194, 201].

\section{Pulsed Light}

\section{Fundamentals}

PL, also known as pulsed UV light, high-intensity broad-spectrum pulsed light, pulsed white light, or intense light pulses, is a nonthermal technology that has gained increasing interest in the last decade, from both the research world and food processing industry, as an alternative to traditional chemical and thermal microbial decontamination methods of foods, food contact surfaces, and equipment [204, 205].

$\mathrm{PL}$ is claimed as an improved version of the UV rays technology, especially for applications requiring rapid and 
Table 2 Edible coatings used for the preservation of different food products, with details on coating formulation

\begin{tabular}{|c|c|c|c|c|}
\hline Product & Coating solution & Plasticizer/surfactant & Active ingredient & References \\
\hline \multicolumn{5}{|l|}{ Fruits } \\
\hline Apricot & Aloe vera gel or basil seed mucilage & - & - & {$[140]$} \\
\hline Blueberries & Gum arabic & Glycerol & Baobab fruit extracts & [48] \\
\hline Blueberries & Fungal chitosan & Glycerol + Tween 20 & Procyanidins from grape seeds & {$[164]$} \\
\hline Dates & Gelatin, chitosan, or guar gum & Glycerol & Olive oil + ascorbic acid & {$[165]$} \\
\hline Figs & Sodium alginate + calcium chloride + chitosan & Lecithin + glycerol & Olive oil & {$[166]$} \\
\hline Grapes & Xanthan gum + calcium chloride & Glycerol + Tween 20 & Ascorbic acid & {$[51]$} \\
\hline Guava & Chitosan & - & $\mathrm{ZnO}$ nanoparticles & {$[25]$} \\
\hline Guava & Carboxymethyl cellulose + stearic acid & Lecithin & Date seed oil & {$[167]$} \\
\hline $\begin{array}{l}\text { Kinnow } \\
\text { mandarin }\end{array}$ & Carboxymethyl cellulose & - & - & {$[32]$} \\
\hline Kiwi & Chitosan hydrochloride & - & - & {$[168]$} \\
\hline Mango & Gum arabic & - & - & {$[47]$} \\
\hline Orange & Aloe vera gel & Glycerol & - & {$[138]$} \\
\hline Papaya & Aloe vera gel + agar gel & - & Ascorbic acid + citric acid & {$[141]$} \\
\hline Peaches & Chitosan & - & Chlorogenic acid & [169] \\
\hline Pears & Cassava starch reinforced by starch nanocrystals & Glycerol & - & {$[20]$} \\
\hline Strawberries & Aloe arborescens gel & - & - & [139] \\
\hline Strawberries & Chitosan & - & Palmaria palmata seaweed extracts & {$[147]$} \\
\hline Strawberries & Fucoidan from Laminaria japonica seaweed & - & - & {$[148]$} \\
\hline Strawberries & Chitosan & Glycerol & - & {$[170]$} \\
\hline Strawberries & Maltodextrins + whey protein isolates & PGPR & Water in olive oil emulsion & {$[171]$} \\
\hline Sweet cherries & Sodium alginate + calcium chloride or chitosan & Glycerol & Olive leaf extracts & {$[143]$} \\
\hline \multicolumn{5}{|l|}{ Vegetables } \\
\hline Broccoli florets & Modified chitosan & - & Mandarin oil nanoemulsion & {$[172]$} \\
\hline Brussels sprouts & Sodium carboxymethyl cellulose & $\begin{array}{l}\text { Candelilla wax }+ \\
\text { Tween } 40\end{array}$ & & [173] \\
\hline Green beans & Modified chitosan & - & Mandarin oil nanoemulsion & {$[9,12]$} \\
\hline Romaine lettuce & Chitosan hydrochloride & - & - & {$[168]$} \\
\hline Rucola & Modified chitosan & - & Lemon oil nanoemulsion & {$[174]$} \\
\hline Spinach & Nanocellulose (from hemp trunks) & - & - & {$[175]$} \\
\hline Tomatoes & Pectin + corn flour & Glycerol & - & {$[176]$} \\
\hline Tomatoes & $\begin{array}{l}\text { Ethanolic extracts of the leaves and pods of } \\
\text { cocoa, leaves, and hulls of coffee }\end{array}$ & $\begin{array}{l}\text { Glycerol + sodium } \\
\text { hypochlorite }\end{array}$ & - & [144] \\
\hline \multicolumn{5}{|c|}{ Fresh-cut fruits and vegetables } \\
\hline Apple & Sodium alginate + calcium chloride & Glycerol & Thyme EO + ascorbic acid + citric acid & {$[177]$} \\
\hline $\begin{array}{l}\text { Cantaloupe } \\
\text { melon }\end{array}$ & Sodium alginate + calcium chloride & Glycerol & Thyme EO + ascorbic acid + citric acid & {$[178]$} \\
\hline $\begin{array}{l}\text { Cantaloupe } \\
\text { melon }\end{array}$ & Carboxymethyl cellulose or chitosan & - & Citral nanoemulsion & [179] \\
\hline $\begin{array}{l}\text { Cantaloupe } \\
\text { melon }\end{array}$ & Fungal chitosan & - & - & [152] \\
\hline Cucumber & Chitosan & - & - & {$[180]$} \\
\hline Eggplants & Soy protein isolate & Glycerol + beeswax & - & {$[181]$} \\
\hline Globo artichoke & Locust bean gum & Glycerol & Foeniculum vulgare EO & {$[181]$} \\
\hline Lotus root & Xanthan gum + chitosan & - & - & {$[182]$} \\
\hline Mango & Sesame proteins + guar gum + calcium chloride & Glycerol & Fresh mango puree & {$[183]$} \\
\hline Papaya & Sodium alginate & $\begin{array}{l}\text { Polyoxyethylene } \\
\text { sorbitan monooleate }\end{array}$ & Thyme EO or oregano EO & {$[29]$} \\
\hline Pineapple & Sodium alginate & Glycerol & Citral nanoemulsion & {$[184]$} \\
\hline \multicolumn{5}{|l|}{ Fish } \\
\hline Hake medallions & Whey protein isolates & Glycerol & Oregano EO & {$[185]$} \\
\hline
\end{tabular}


Table 2 (continued)

\begin{tabular}{|c|c|c|c|c|}
\hline Product & Coating solution & Plasticizer/surfactant & Active ingredient & References \\
\hline Huso huso fillets & Chitosan & - & Fennel EO & [186] \\
\hline Tilapia fillets & Chitosan & - & Tartary buckwheat extracts & {$[142]$} \\
\hline Trout fillets & Sodium alginate & - & Resveratrol & [187] \\
\hline Trout fillets & Quinoa starch & Glycerol & Lemon or sage EO & [188] \\
\hline \multicolumn{5}{|l|}{ Meat } \\
\hline Beef & Gelatin + chitosan & Glycerol & - & [189] \\
\hline Beef & Chitosan & - & - & {$[190]$} \\
\hline Beef & Whey protein nanofibrils & Glycerol & Titanium dioxide nanotubes & [191] \\
\hline Chicken breast & Whey protein isolates & Glycerol & Oregano EO & [192] \\
\hline Chicken breast & Chitosan & Glycerol + Tween 80 & Zataria multiflora Boiss. EO & [193] \\
\hline Pork & Chitosan + gelatin & - & Grape seed extracts & [39] \\
\hline Pork & Sodium alginate + carboxymethyl cellulose & Glycerol & Epigallocatechin gallate & [194] \\
\hline \multicolumn{5}{|l|}{ Miscellaneous } \\
\hline Eggs & Sweet potato starch & Glycerol + Tween 80 & Thyme EO & {$[195]$} \\
\hline Eggs & Whey protein isolates + pectin + transglutaminase & Sorbitol & - & [196] \\
\hline Fiordilatte cheese & Sodium alginate + calcium chloride & - & $\begin{array}{l}\text { Freeze-dried Lactobacillus rhamnosus }+ \\
\text { fructooligosaccharides }\end{array}$ & {$[197]$} \\
\hline Gouda cheese & Zein & - & Laurel EO & [198] \\
\hline Gouda cheese & Whey protein & Glycerol & Lactoperoxidase + Bunium persicum $\mathrm{EO}$ & [199] \\
\hline Kashar cheese & Whey protein concentrate & Glycerol & Williopsis saturnus killer yeast & {$[200]$} \\
\hline Manchego cheese & Chitosan & Glycerol + Tween 20 & Santolina chamaecyparissus L. extracts & [201] \\
\hline $\begin{array}{l}\text { Pholiota nameko } \\
\text { mushroom }\end{array}$ & Sodium alginate & Glycerol & Thyme EO + L-cysteine + nisin & {$[202]$} \\
\hline $\begin{array}{l}\text { Shiitake } \\
\text { mushrooms }\end{array}$ & Chitosan + guar gum & Glycerol & - & {$[74]$} \\
\hline $\begin{array}{l}\text { Goat and Tybo } \\
\text { cheese }\end{array}$ & Agar & Glycerol & Enterocins from E. avium & {$[18]$} \\
\hline Walnut kernels & Walnut flour protein & Glycerol & - & [203] \\
\hline
\end{tabular}

effective disinfection treatments. UV radiation is the part of the electromagnetic spectrum of sunlight, in the range 100-400 nm, which can be subdivided into UV-A (315$400 \mathrm{~nm}), \mathrm{UV}-\mathrm{B}(280-315 \mathrm{~nm}), \mathrm{UV}-\mathrm{C}(200-280 \mathrm{~nm})$, and the vacuum UV range (100-200 nm). UV-C has the strongest germicidal effect and is widely used to inactivate microorganisms [206]. The classical UV-C treatment works in a continuous mode, called continuous wave (CW)-UV light, and typically involves the exposure (from minutes to hours) of the substrate to be disinfected to low power $(5-80 \mathrm{~W})$ monochromatic light $(254 \mathrm{~nm})$ emitted by a low-pressure mercury lamp [204]. In the PL process, instead, food or nonfood materials are exposed to a successive repetition of short (100 ns to $1 \mathrm{~ms}$ ) high-intensity pulses (flashes) of polychromatic light (180-1100 nm), including UV (180-400 nm), visible (400-700 nm), and infrared (700-1100 $\mathrm{nm}$ ) regions, emitted by an inert gas (e.g., xenon) lamp [13]. The light used for food processing applications is typically pulsed at 1 to 20 flashes per second at an energy density in the range of about 0.01 to $50 \mathrm{~J} / \mathrm{cm}^{2}$ at the surface [13].
The inactivation effectiveness of PL has been tested against a great variety of pathogenic and spoilage microorganisms, including bacterial species (both as vegetative cells or spores), yeast, fungi, and viruses spread on agar, food, or food contact surfaces or suspended in fluids (air, water, liquid foods) [13, 207-209].

The lethal action of the PL process is attributed to the effects of the high peak power and the UV component of the broad spectrum of the light flashes, which result in the coexistence of different inactivation mechanisms. In particular, the UV component of PL can be absorbed by DNA and other components of the cell, thereby causing photochemical damage, which kills microorganisms [210]. Moreover, PL spectrum includes visible and near-infrared regions, which convey heat to the surface of the processed substrate, inducing a local instantaneous increase of the temperature of a thin (a few $\mu \mathrm{m}$ thick) surface layer only to an extent sufficiently high to destroy microbial cells (photothermal effect) [211, 212]. Additionally, structural damages caused by the high-power pulsing effect (photophysical effect) have been also detected through microscopy detection as well as the quantification of 
the leakage of intracellular matters, such as proteins, which was not observed when the same microbial cells were exposed to CW-UV light treatment [213, 214]. The relative importance of each mechanism may depend on the peak power of the light pulses, the composition of the emitted light spectrum, and the type of microorganism as well as the optical properties of the target substrate, among others.

The occurrence of this multitarget microbial inactivation mechanism, along with the high emission power, which is likely to increase the capability of PL to penetrate the treated substrate, can explain the generally reported higher sterilization effectiveness of PL in comparison with CW-UV [214]. Moreover, PL is a fast and easily operating, residue-free decontamination technology, which is characterized by low energy consumption, can be combined with other disinfection methods, and is suitable for integration in industrial processing lines, enabling high product throughput.

\section{Technical Aspects and Pulsed Light Equipment}

\section{Definitions and Terminology}

Before providing information concerning PL equipment and processing, it is worth giving the definition and units of the main parameters characterizing this technology [215].

- Pulse duration (or pulse width) is the time interval (ns to ms) during which the light energy is delivered.

- Number of pulses (or flashes) is the total number of pulses or flashes of light delivered to the target substrate.

- Pulse repetition frequency is the number of pulses of light delivered per second (Hertz [Hz]), commonly expressed as pps (pulses per second). Due to the design features of the lamp, in PL systems, the pulse frequency is typically limited to a few Hertz. However, higher pulse frequency can be achieved by using two or more lamps, placed and flashed in sequence.

- Exposure time is the actual time (in seconds) of exposure of the substrate to the light flashes and is calculated as the number of pulses times the pulse width.

- Peak power, $\phi$, is pulse energy divided by the pulse duration and (in watts $(\mathrm{W})$ ).

- Fluence rate $\left(F_{\mathrm{o}}\right)$ is the radiant power passing from all directions through an infinitesimally small sphere of cross-sectional area, $\mathrm{d} A$, divided by $\mathrm{d} A$ (in $\mathrm{W} / \mathrm{m}^{2}$ ).

- Fluence $(F)$ (or PL dose) is the total radiant energy from all directions passing through an infinitesimally small sphere of cross-sectional area $\mathrm{d} A$, divided by $\mathrm{d} A$, for a certain time (in $\mathrm{J} / \mathrm{m}^{2}$, even though in PL technology, it is often expressed in $\mathrm{J} / \mathrm{cm}^{2}$ ). The fluence is the fluence rate multiplied by the exposure time. However, when the substrate exposed to PL treatment is a given volume of a liquid containing a certain microbial load expressing the
PL dose as total radiant energy per unit area is not correct. Thus, several authors have proposed that the fluence (in $\mathrm{J} /$ $\mathrm{L}$ or $\mathrm{J} / \mathrm{mL}$ ) is correctly defined, according to Eq. 1, as the PL energy output (radiant power, $\Phi$, in $\mathrm{W}$ ) delivered to a volumetric flow $(Q$, in $\mathrm{L} / \mathrm{s}$, or $\mathrm{mL} / \mathrm{s})$ :

$F=\frac{\phi}{Q}$

The evaluation of the operational costs based on the volumetric electrical energy input $(\mathrm{J} / \mathrm{L}$ or $\mathrm{J} / \mathrm{mL})$ allows comparing the results of PL treatments carried out with different PL units as well as with those obtained utilizing other inactivation technologies [206].

\section{Pulsed Light Generation and Equipment}

PL is generated using pulsed power technologies that involve the generation of high-power electrical pulses and their transformation into high-power light pulses. The systems used for PL applications typically include a power/control module, a lamp housing with a flash lamp, a treatment chamber, and an auxiliary equipment, such as pumps, cooling systems, and devices to measure temperatures and fluence rate or fluence.

The power/control module is used to manage the process, start the flashes, control the treatment time, and modulate the generation of high-power electrical pulses to obtain the desired configuration of the pulse energy and rate. In particular, during PL treatment, the power/control module converts alternating current (AC) into direct current (DC), cyclically accumulated in a capacitor bank, and released by a special switch as high-voltage electric pulses through the lamp unit. The latter consists of one or more lamps with quartz envelopes, each equipped with two electrodes, typically filled with inert gases (e.g., xenon, krypton). The inert gases effectively convert the pulsed electrical energy into a broad spectrum of pulsed radiant energy. Approximately $25 \%$ of the wavelength lies in the UV range, $45 \%$ in the visible range, and $30 \%$ in the infrared range. Moreover, the shape (linear, spiral, etc.) and the size of the lamp can be customized for the specific application to ensure uniform irradiation of the target surface (http://www.xenoncorp.com/).

The PL equipment can be operated either in batch or in continuous flow mode, as schematized in Fig. 1.

Batch systems are the most widespread and used for preliminary investigations at the laboratory scale on the effects of the main PL treatment parameters on the decontamination of liquid and solid products. Figure 1a shows a schematic of a typical laboratory-scale batch system. It consists of a chamber in which the solid or liquid sample is placed on an adjustable tray that allows regulating the distance between the sample and light source. A housing lamp with a xenon lamp is generally mounted on the upper part of the treatment chamber. 

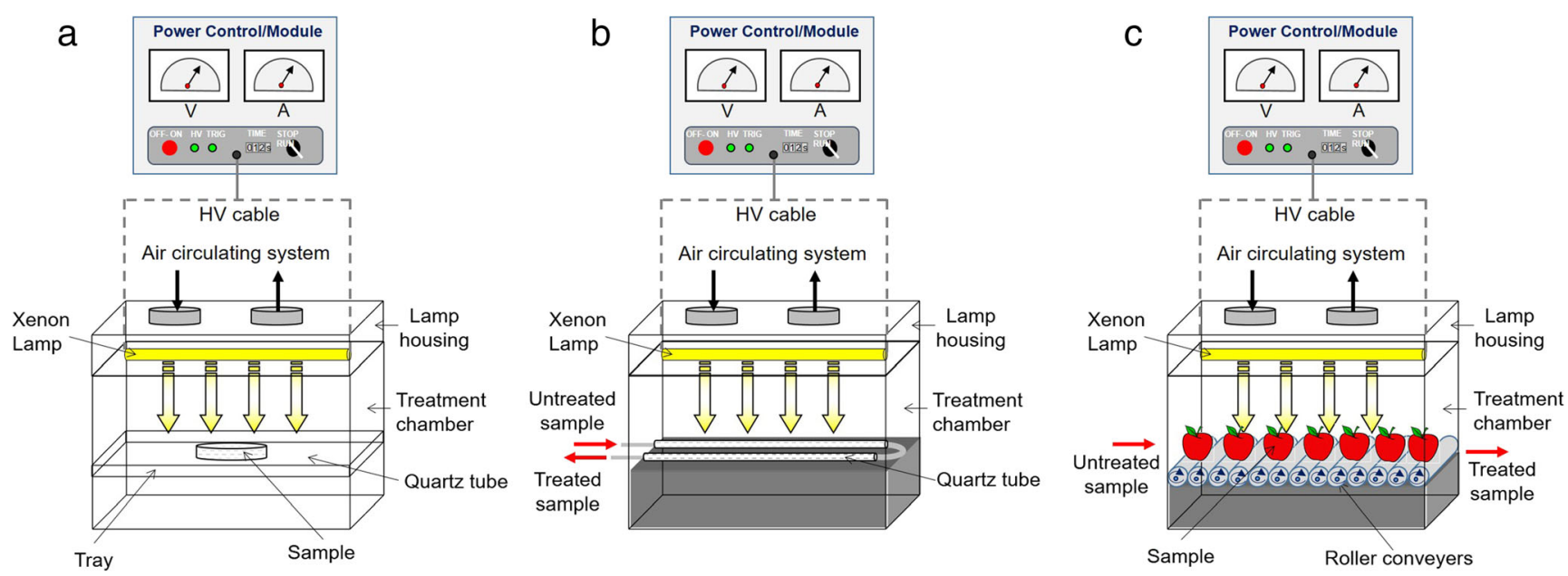

Fig. 1 Schematic of pulsed light systems for batch treatments (a), continuous treatments of liquid food (b), and continuous treatments of solid food (c)

Multiple lamps can be used to ensure more uniform irradiation of the product surface. A high-voltage cable connects the lamp to the power/control module, which allows setting the treatment time or number of flashes to be delivered to the sample. The heat unavoidably generated by the lamp is removed by a cooling system, using water or filtered air circulation.

Although most of the equipment currently used are at the laboratory scale and operate batch-wise, several works have highlighted the advantages of continuous toward discontinuous flow systems, such as processing larger quantities of products, and more efficient microbial inactivation, due to the improved light exposure of the product and enhanced treatment uniformity [208].

Continuous flow systems can be designed to process either liquid or solid products. To treat liquid products, the liquid is pumped in the treatment chamber through a quartz tube which allows the penetration of light flashes (Fig. 1b). The exposure time and, consequently, the total number of flashes or fluence delivered to the product depend on both the volume of the quartz tubes and the flow rate. Optimization of geometry and the number of quartz tubes, along with their relative position to the lamp, is required to ensure maximum disinfection effectiveness with minimum energy consumption. Packaged or unpacked solid products, instead, can be loaded in the treatment chamber with conveyor belts or roller conveyors moving the product through the irradiated zone at the speed that guarantees the desired exposure time (or fluence) (Fig. 1c).

Several laboratory-scale PL systems are provided by different manufacturers. The most commonly used ones are the RS-3000C SteriPulse-XL system (Xenon Corp., Wilmington, MA, USA) [216]; the XeMaticA-2L system (SteriBeam Systems GmbH, Germany) [217], equipped with a single linear Xenon flash lamp; and the PL mobile decontamination unit (Claranor, Rouaine, France) equipped with 4 xenon lamps (JA series, Verre et Quartz, Bussy Saint Georges, France) [218]. All these equipment differ for the wavelength distribution, pulse duration $(50-360 \mu \mathrm{s})$, pulse repetition rate (0-5 Hz), input voltage (100-3800 V), and the cooling system of the lamp (forced air or circulating water). For continuous flow treatment of liquids, only a few laboratory-scale PL systems are currently available, which include in-house-developed equipment [208, 219, 220] or commercial dynamic flowthrough pilot unit (Maria PUD system, Claranor, Manosque, France) [221].

Commercial-scale PL systems are nowadays successfully used in the food industry, but only for the decontamination of packaging material (e.g., caps, cups, trays, and steel cans, bottles, and lids). These PL units can be easily integrated into the existing continuous processing lines to decontaminate up to $4,000-90,000$ items/h and can provide decontamination levels with a $3-5 \log$ reduction of the reference microorganisms (http://www.claranor.com/).

\section{Factors Affecting the Effectiveness of Pulsed Light Microbial Decontamination Treatment}

Several studies have demonstrated that the effectiveness of PL treatment depends on many factors that are critical to the outcome of the process as they may affect the treatment uniformity and the level of energy dose than ultimately reaches the target [204, 222, 223]. These factors can be classified essentially into four groups: processing parameters, design parameters, product properties, and microbial factors [223].

Processing Parameters Processing parameters markedly affect microbial inactivation achieved by PL treatments. The most important factor determining the inactivation effectiveness of $\mathrm{PL}$ is the total fluence (or the total amount of photons) incident on the sample. Therefore, the required decontamination effect is obtained properly optimizing the parameters affecting the total fluence, namely the distance of the substrate from the lamp, the exposure time, the number and duration of pulses, 
and the input. With increasing the intensity of these parameters or decreasing the distance of the product from the lamp, the total fluence increases and, hence, microbial inactivation is enhanced [204, 208, 222, 223].

Appropriate PL dosimetry is fundamental to compare results and for process scale-up [215]. In this regard, fluence measurements should be standardized and precaution should be taken in reporting the energy dose at the substrate surface or within the substrate, which is substantially different from the energy delivered by the light source. This is because of the radiation loss attenuation across the path length of the treatment medium due to light absorption and scattering phenomena [221, 224].

The composition of the PL spectrum is another important process parameter determining the antimicrobial action of $\mathrm{PL}$ technology [217, 225-227]. Although the effectiveness of the full spectrum of high-intensity PL has been widely demonstrated to be effective against different microbial species, the photochemical effect of UV-C plays a major role in microbial inactivation. Therefore, depending on the specific application, the use of wavelength filters, such as solid filters (e.g., glass UV filters) or liquid filters (e.g., $\mathrm{CuSO}_{4}$ solution) [209, 217], or the adjustment of electrical current [228] allows selecting the most suitable wavelength ranges emitted by the lamp to achieve the desired microbial inactivation while avoiding or minimizing alterations of the substrate properties.

The temperature increase in the substrate exposed to PL treatment is mainly a function of the total amount of energy delivered by the light source to the target, as well as of the pulse frequency and composition of the PL spectrum. Preventing overheating is of utmost importance to avoid seriously compromising food quality, especially during long processing time. To this purpose, an efficient cooling system is incorporated in the equipment, and an appropriate pulse repetition rate and distance between the product and the lamp source must be selected [208].

Design Parameters Geometry and setup of the treatment chamber, lamp, and deflector as well as the number of lamps significantly influence the treatment uniformity and, hence, the efficiency of the PL process and product quality.

Product Properties The composition and physical properties of the substrate exposed to PL treatment, which can enhance absorption, reflection, or scattering phenomena of the incident light or induce shading effect, affect the effective radiation dose reaching the target, thus biasing treatment effectiveness and uniformity. In this regard, proteins and fat-rich substrates are unsuitable for PL treatment, since these components can competitively absorb light thus decreasing PL inactivation effectiveness, while light absorption does not occur in carbohydrates [222]. Therefore, food products with high protein and fat content have little potential to be efficiently decontaminated by PL, while vegetables and fruit are eligible for PL treatment [204].

Different physical properties of the substrate are playing a role when flashing solid or liquid foods. Opacity, turbidity, coloring compounds, viscosity, and suspended particles may significantly hinder either the penetration of light pulses and light absorption into the liquid food causing a significant decrease in PL treatment effectiveness and uniformity [208, 221]. Therefore, while PL can be successfully applied to transparent liquid (e.g., drinking water and clear fruit juices), in opaque liquid foods, such as orange juice or milk, the effect of PL might be limited only to the superficial layer of the substrate. Moreover, solid product properties, including topography, reflectivity, hydrophobicity of the treated surface, color, and opacity, greatly influence the successful PL microbial inactivation $[209,229]$. For example, surface roughness, crevices, or pores may shade or hide microbial cells during treatment. The hydrophobicity of the food surface may affect the distribution of microbial cells promoting the formation of cell clusters and reducing PL inactivation. Furthermore, a high surface reflectivity, causing a decreased light absorption of the microbial cells, could lead to poor inactivation [229, 230].

The limitations to the use of PL technology in the decontamination of solid matrices are common to other methods applied in the food industry to decontaminate raw fruits and vegetables or packaging material, such as washing with solutions containing chlorine, peracetic acid, or hydrogen peroxide $[205,209]$. The challenge is, therefore, represented by engineering solutions as the re-design of the equipment to promote more uniform surface irradiation of rough surfaces of solid and opaque liquid products [13, 204]. Additionally, absorption-enhancing agents (e.g., carotenoids, fat), sprayed on the surface or added to the formulation of foods, have been suggested to maximize the absorption of the bactericidal wavelength of PL [209, 231].

Microbial Factors The lethal effect of PL also depends on the intrinsic properties of the microbial cells, namely the type of microorganism, growth phase, and inoculum size. For example, it is widely recognized that PL susceptibility of microorganisms exhibits the following trend: Gram-negative bacteria $<$ Gram-positive bacteria $<$ yeasts $<$ bacterial spores $<$ molds $<$ viruses [13]. The growth phase is another microbial factor which may affect the light sensitivity of microorganisms. In general, microbial cells in stationary growth phase show greater resistance to PL than cells in either lag or exponential phase [222]. Moreover, PL decontamination is less effective in highly contaminated products due to light attenuation phenomena [204]. In such a case, microorganisms may overlap or aggregate, the outer microorganisms shading those located underneath or inside the cluster [222, 232], and, consequently, nonuniform treatments and reduced PL inactivation effectiveness are likely to occur. 
In conclusion, there is a need for more systematic and accurate studies on the effect of the most relevant factors affecting the successful application of the PL process, which should include also the standardization of the measurements of the treatment dose as well as of the experimental procedures used by different research groups. Additionally, the design of PL systems should be optimized for each application (e.g., inducing a turbulent flow or enhancing the mixing conditions) to improve the treatment homogeneity and, thus, increasing the microbicidal effects of this technology. Finally, the need of integrating proper cooling systems in the treatment chamber should be emphasized to minimize temperature buildup during the pulse treatment.

\section{Main Applications to Food Products}

PL treatment is a fast, environmentally friendly, nonthermal technology with many potential applications in the food industry for food processing and food contact surface decontamination. In this regard, the technology appears especially interesting for the decontamination of food packaging material, fresh and fresh-cut produce prior to or after packaging, as well as for the stimulation of fruit physiology to promote the production of functional compounds. Since 1996, PL irradiation has been approved by the US Food and Drug Administration to decontaminate food or food contact surfaces, provided that the treatment uses a xenon lamp with an emission wavelength between 200 and $1000 \mathrm{~nm}$, a pulse duration not exceeding 2 $\mathrm{ms}$, and a cumulative energy level not exceeding $12 \mathrm{~J} / \mathrm{cm}^{2}$ (Code of Federal Regulation, CFR: 21CFR179.41 [233]).

Despite the recent advancements of PL technology, the increasing number of PL manufacturers, and the number of studies on surface decontamination, currently, PL has been successfully applied at the industrial scale only to decontaminate food packaging materials (http://www.claranor.com/). The utilization of PL treatments at the pilot or industrial scale to extend shelf life and improve the quality of food products is still lacking.

The capability of PL to inactivate microorganisms, either artificially inoculated or naturally present on the surface of food products, before packaging has been extensively investigated on a large number of fruits and vegetables. The results reported in the literature demonstrated that, although complete inactivation is not possible, PL treatments allowed obtaining from 1 to $6 \log$ reduction of the microbial load while preserving quality attributes of foods [13]. The different inactivation levels reported often arise from equipment type and configuration, experimental protocols, and fluence measurements other than individual characteristics of the microbial strains.

For example, Bialka and Demirci [234], by applying a PL treatment at fluences of $23-59 \mathrm{~J} / \mathrm{m}^{2}$, observed a reduction of 2-4 $\log$ CFU/mL of Escherichia coli O157:H7 inoculated on the surface of blueberries, raspberries, and strawberries. In another study, Aguiló-Aguayo et al. [235] assessed the impact of PL, at a fluence of 2.3 or $5.4 \mathrm{~J} / \mathrm{cm}^{2}$, on surface decontamination of native microflora or inoculated Saccharomyces cerevisiae of red-ripe tomatoes. PL treatment was more effective against the inoculated microorganisms $(2.3 \log \mathrm{CFU} / \mathrm{mL}$ reduction) than total microflora ( $1 \log \mathrm{CFU} / \mathrm{mL}$ reduction). The authors also investigated the impact of PL exposure on physicochemical (color, texture, weight) and nutritional properties of tomatoes during storage at $20{ }^{\circ} \mathrm{C}$ for 15 days. Interestingly, they found that PL treatment did not induce any changes in physicochemical properties of tomatoes, while the nutritional properties of the PL $\left(30 \mathrm{~J} / \mathrm{cm}^{2}\right)$-treated samples remained unaffected (ascorbic acid) or were improved (total lycopene, $\alpha$-carotene, and $\beta$-carotene).

The in-package decontamination of food products with PL is also of great interest for the future commercial application of this technology, since it allows the treatment of food already packed, avoiding undesired post-treatment recontamination. Nevertheless, only a few publications, so far, focused on inpackage decontamination of food products, most of them referred to decontamination of meat and meat products, fish, and, to less extent, of fruits and vegetables [236]. Therefore, more research efforts are required to assess the feasibility of inpackage PL processing of foods. Future studies should investigate not only the effects of physical properties of the products, processing conditions, and susceptibility of the native microflora to PL exposure, but also the chemical (e.g., composition), physical (e.g., thickness), and optical properties (e.g., UV transmissivity) of the packaging films. Moreover, particular attention should be paid to evaluate the structural and barrier property changes of packaging and migration of compounds from packing materials to foods induced by PL.

Finally, several recent studies reported the potential of PL in modulating the metabolic activity of fresh produce [237, 238]. The main findings were the delay of senescence and deterioration of fruits and vegetables during storage in MAP and, interestingly, the stimulation of plant natural defenses against fungal diseases and the biosynthesis of bioactive antioxidant compounds [216, 237-239]. For example, it has been shown that PL exposure can significantly increase lycopene content in tomatoes [216], the amount of anthocyanins and phenolic compounds in figs [240], the phenolic compounds in apples [239] and persimmons [241], and the vitamin $\mathrm{D}_{2}$ in mushrooms [242]. It is particularly noteworthy that the industrial implementation of this kind of PL treatment already took place [243].

\section{Combined Edible Coating and Pulsed Light Treatments}

Several methods have been proposed for the preservation of fresh products, which could allow better retention of their 
quality attributes and overcome the limitations and drawbacks of traditional thermal treatments, especially their strong impact on the nutritional, functional, and sensorial properties of products [244]. Some of the nonthermal preservation methods that have been investigated include the deposition of ECs loaded with additives (active EC), the use of controlled atmosphere storage or modified atmosphere packaging, high pressure, PL, pulsed electric fields and ultrasounds treatments, and ionizing radiations [245]. However, often the hurdle approach is more useful and successful than the single method, the two main advantages relying upon the superimposition of the effects of the different preservation factors and to the possibility to tune the more expensive stress to lower intensities, which positively affect the costs and the energy expenditure of the innovative technology [11].

In the "Edible Coatings" and "Pulsed Light" sections, the advantages of using active ECs and PL for food preservation have been outlined, including the reduction of the incidence of food-borne pathogens and spoilage microorganism, either through their inactivation or growth inhibition, the extension of the shelf life of the produce, and the prevention of food quality losses along the distribution chain. By combining these two hurdles, efficient food preservation methods can be developed, exploiting the different antimicrobial mechanisms of the two technologies and different time scales of operation (PL causes an immediate microbial reduction on the food surface, while active ECs ensure the inhibition of microbial growth over an extended time).

ECs and PL treatment can be applied to the product in two different sequences: EC followed by PL treatment of foods (before packaging or eventually already in-package), or PL treatment applied to the product which is then covered with the EC. Following the first approach, residual or crosscontamination from the coating surface is avoided, contributing to extend the shelf life of the product. The application of PL on coated products facilitates their manipulation allowing a better exposure to light pulses of the entire surface, which is not possible for packaged products. Despite the screening effects of the packaging could reduce PL treatment effectiveness, the exposure of foods to light flashes after packaging is particularly advantageous to extend the shelf life of products due to the removal of residual contaminations both on foods and package.

Following the second approach, PL is used to decontaminate the surface of the products before their stabilization obtained by applying the EC. This strategy is particularly useful when a significant reduction of the microbial population on the product surface is needed. In this case, cross-contamination should be avoided, and therefore, edible coatings must be applied through spraying or electrospraying techniques. Moreover, following this approach, the process becomes more laborious, being two stages of drying or dripping off from the product necessary before the PL treatment and after the coating application.

These two alternative processing strategies are depicted in Fig. 2, reporting a generic processing line for fruit and vegetable transformation [246] in which the EC and PL preservation methods are implemented individually (Fig. 2a) or in combination (Fig. 2b). Fresh-cut fruits and vegetables are very critical to be processed. The cutting surface, consisting of wounded tissues, is extremely susceptible to softening, browning, and discoloration phenomena [247] and, due to the release of the intracellular compounds, is exposed to microbial and enzymatic attack [174]. However, fresh-cut fruits and vegetables are a value-added convenience food in high demand for consumers oriented toward natural and healthy products. Therefore, the use of the hurdle approach, as shown in Fig. 2b, to extend their shelf life is fully justified and understandable, and most of the studies on the use of combined PL and ECs have been targeted on fresh-cut fruit and vegetable preservation, as discussed in the "Transmittance of PL Through the Coating Layer" section.

\section{Possible Interactions Between PL Treatment and Coating Application}

\section{Effect of PL on Coating Properties}

A first important aspect to consider in the combination of PL with the EC is concerned with the possible modifications of the coating when exposed to a PL treatment.

Previous studies have reported that the main modifications observed in edible films subjected to PL can be related to the occurrence of cross-linking reactions, due to photopolymerization effects, and film deterioration phenomena, such as depolymerization and retrogradation, whose relative extent depends strongly on film composition. For example, taro starch-based films, characterized by a low amylose content, when exposed to PL, underwent mainly a physical modification through photo-polymerization, with the induced slight cross-linking that improved starch-glycerol interactions [248]. Conversely, cassava starch-based films, characterized by high amylose content, did not show any evidence of crosslinking but exhibited a measurable deterioration due to a photodegradation effect [248]. Other authors reported that PL-treated starch-based films exhibited an increase in crystallinity, reduced chain mobility, and formed more closed structures, independently of their amylose content [249, 250]. Furthermore, techno-functional characterization of PLtreated starch-based films showed that, under the conditions of maximum fluence permitted by the US FDA $\left(12 \mathrm{~J} / \mathrm{cm}^{2}\right)$, photodegradation reactions prevailed, independently on amylose content of starch, and PL-treated films exhibited a significant deterioration of their properties, as shown by an increase in contact angle, surface roughness, and crystallinity and a 

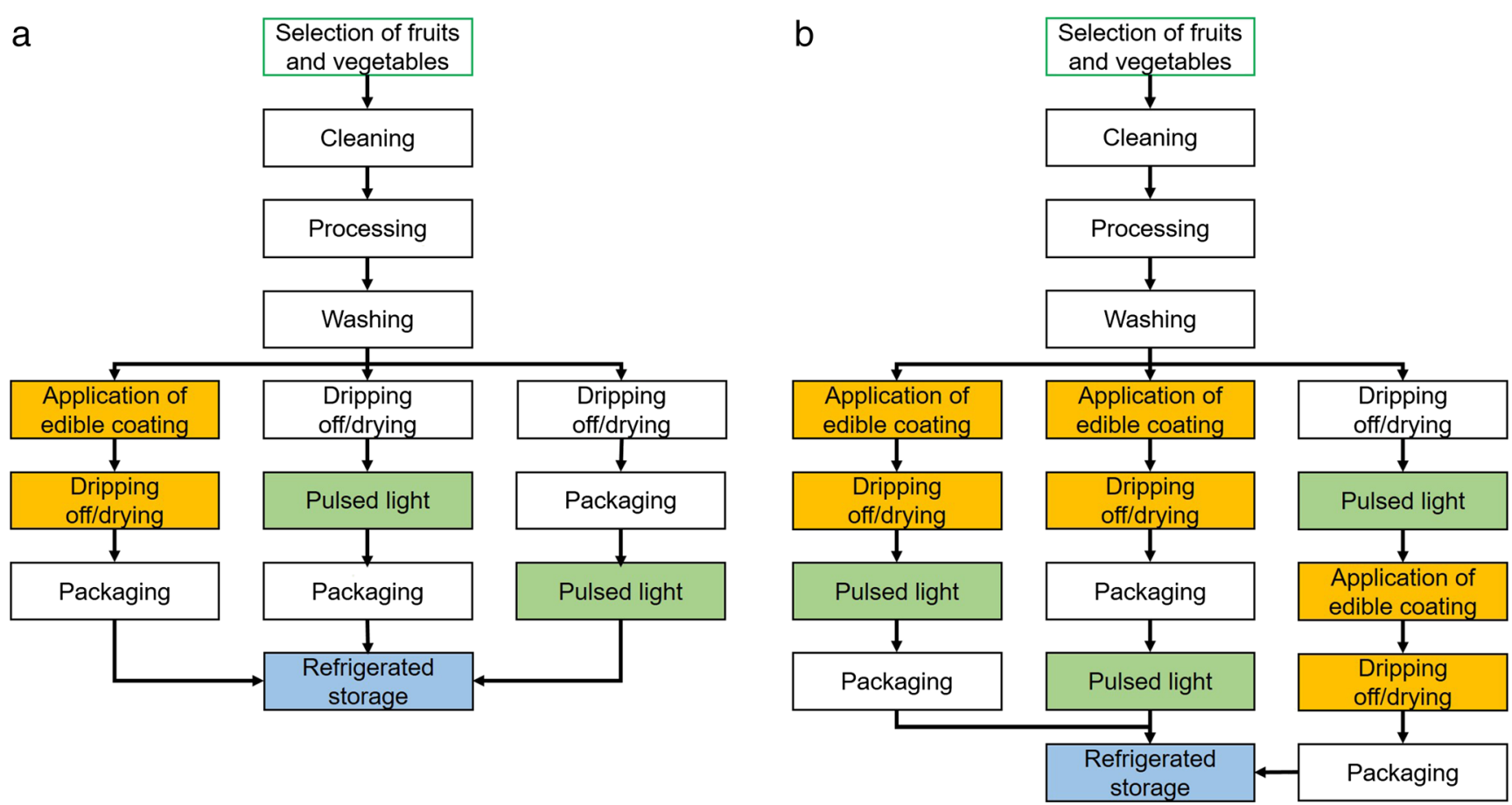

Fig. 2 Process flow diagram of fresh-cut fruit and vegetable processing with the inclusion of edible coating application or pulsed light treatments, individually (a) and combined (b)

decrease in tensile strength, transparency, and water content [251]. The degradative effect of PL treatment was observed also for casein-based films, which exhibited a significant deterioration of mechanical properties, e.g., a reduction in Young's modulus and maximum stress values, and surface characteristics, e.g., increase in wrinkle density and film opacity [252]. In contrast, no measurable effects on mechanical properties, such as tensile strength, elongation at break, and Young modulus, were recorded for starch-based films used as packaging for cheddar cheese, upon application of a PL treatment at a fluence varying in the range from 1 to $12 \mathrm{~J} / \mathrm{cm}^{2}$ [253].

These partially contradicting data derive from the limited number of studies on the effect of PL treatment on edible films and coatings, which prevents to draw general conclusions. The analysis of the data reported for PL treatment of packaged products can, however, provide some additional elements. When a packaging material is subjected to PL, it is important to monitor not only the physical and mechanical stability of the films but also the potential chemical migration, which might cause safety concerns [254]. Changes in mechanical properties, such as reduced strength or extensibility, and impact strength or cracking are generally reported, and the alteration of the mass transfer properties, namely permeation, migration, and scalping, can take place [255]. However, these phenomena are likely to occur upon intense PL treatments, whereas in-package treatment carried out at milder conditions does not cause any measurable effect on film properties [254]. For example, polypropylene films, treated with PL at 1.27
$\mathrm{J} / \mathrm{cm}^{2}$ fluence, showed no significant changes in elastic modulus, yield strength, percent elongation at yield point, maximum tensile strength, and percent elongation at break [256].

In conclusion, due to the lack of available data, no prediction can be made on the effect of PL on the techno-functional properties of ECs, and preliminary experiments should be carried out to verify their compatibility. In any case, the risks associated with the migration of the coating components into the foods are less critical than for polymeric films, where, instead, potentially toxic compounds are present.

\section{Transmittance of PL Through the Coating Layer}

A second important aspect to consider is the transmittance of PL through the coating layer. No specific studies are available on ECs, and therefore, some considerations can again be made on the basis of the literature data concerning the PL treatment of packaged products. As a general recommendation, a successful in-package application of PL requires the selection of proper packaging materials, characterized by high light transmissibility, in particular of the UV fraction. Therefore, polymeric matrices that may interfere with light absorption because of their intrinsic nature or because they contain additives, such as polyphenols or anthocyanins, should be avoided [254].

As already mentioned, in PL treatments, UV light below $270 \mathrm{~nm}$ is of greatest relevance for the decontamination processes [226]. Therefore, materials with a cutoff wavelength, which is defined as the wavelength below which the light 
transmission is negligible (absorbance of 1.0), below $180 \mathrm{~nm}$, such as polyethylene (PE) and polypropylene (PP), are very suitable for in-package applications, followed by polyvinyl chloride (PVC) and polyamide (PA) with a cutoff of about $240 \mathrm{~nm}$, polystyrene (PS) and polycarbonate (PC) with a cutoff comprised between 270 and $280 \mathrm{~nm}$, and polyethylene terephthalate (PET) with a cutoff of $310 \mathrm{~nm}$ (all given for 10 - $\mu$ m-thick films [254]). Moreover, a higher degree of polymer crystallinity, the presence of morphological inhomogeneity, and the inclusion of additives are also reported to affect light transmittance [254, 257]. Previous studies have shown that a $12-\mu \mathrm{m}$ polyethylene film, a $48-\mu \mathrm{m}$ polyamide/polyethylene/vinyl acetate-based copolymer, and a $60-\mu \mathrm{m}$ polyamide/polyethylene copolymer did not cause any reduction in the PL treatment (fluences of 0.175 and $0.35 \mathrm{~J} / \mathrm{cm}^{2}$ ) effectiveness against Listeria monocytogenes [258]. Similarly, tests carried out on wrapped products showed that PL was suitable for the treatment of packaged chicken frankfurters in PP films [256] and chicken breast in different films (e.g., PP, PVC, PET/PP) [259, 260].

In the case of edible films, it was demonstrated that PL, with a fluence comprised between 9.2 and $12.3 \mathrm{~J} / \mathrm{cm}^{2}$, can pass through starch-based films without losing effectiveness, as light in the range $200-1100 \mathrm{~nm}$ is not adsorbed [253]. However, some light absorption was recorded when the films were loaded with antimicrobial compounds, such as sodium benzoate and citric acid [253]. In the case of gellan gum-based EC, enriched with apple fiber and used on fresh-cut apples, the transmittance values of UV-A, UV-B, and UV-C radiation, determined for a film thickness of $155.75 \mu \mathrm{m}$ [261], were $99.3 \%, 99.0 \%$, and $73.0 \%$, respectively, showing that the coating blocked a significant part of the incident UV-C radiation [262].

The lack of sufficient data on the transmittance of PL through ECs, especially as a function of layer composition, thickness, and eventual presence of additives, prevents from drawing a general conclusion also in this case. However, if the contribution of PL treatment applied after the deposition of the $\mathrm{EC}$ is to remove any eventual contamination that occurred on the film surface, the issue of light transmittance becomes not important. Instead, the protection of the food surface from PL radiation might also be appreciated for some photosensitive products.

\section{Main Applications to Food Products}

Based on the considerations reported in the "Combined Edible Coating and Pulsed Light Treatments" section, it is comprehendible that, to date, only a limited number of studies have focused on the utilization of PL in combination with the application of ECs to inhibit microbial growth and to extend the shelf life of food products.
Table 3 reports a survey of the published scientific papers on combined treatments, presenting the main findings for different products treated and providing details on the formulation and application of ECs, PL treatment conditions, and on the sequence of the treatments.

Interestingly, most of the available data concern fresh-cut fruits and vegetables, which represent, as already discussed, an especially critical product characterized by a high added value. Only one article treated the preservation of green beans, which were considered more like a model food (for the comparison with other technologies, across different laboratories $[8,9,12])$ than for the industrial interest for preservation purposes.

In the data of Table 3, all the different strategies discussed in Fig. 2 were investigated, with the prevalence of coating application before PL treatment [8, 262-264, 266, 267] and of coating application followed by packaging and PL treatment on the packaged product $[265,268,269]$,

The PL treatment carried out after coating application is generally preferred when the starting material has a low initial microbial load, as in the case of fresh-cut fruits and vegetables, if properly processed, and resulted to provide a significant contribution to extending the product shelf life, through the preservation of quality parameters and the inhibition of microbial growth. In addition, in some cases, it was also reported that there was an increase in the polyphenolic content of food products, as a consequence of the abiotic stress induced by PL [266].

Remarkably, only two papers considered the application of PL before coating application, in comparison with the application of coating before PL treatment [264, 266]. The application of PL before EC ensured a higher initial microbial inactivation, as shown for fresh-cut mango slices, which can be explained by the fact that the microbicidal effect of PL is not screened by the presence of the coating, which both might exert a protective role on microorganisms and reduce the transmittance of radiation. Interestingly, during a 14-day product shelf life, better quality parameters and microbial stability were observed for the product treated with PL before the coating application [264]; however, the coating application before PL treatment ensured a higher total phenolic content [266].

\section{Conclusions and Perspectives}

Consumers' quest for natural products delivering a high level of convenience has promoted the use of mild preservation technologies for ensuring product safety and retaining the quality attributes of fresh products. Within this frame, EC and PL treatments have recently emerged as very promising for food categories such as perishable high value-added products or fresh-cut fruits and vegetables. 
Table 3 Combined pulsed light and edible coating treatments, with details on pulsed light conditions, formulation and application of edible coatings, the order of the treatments, and food storage conditions

\begin{tabular}{|c|c|c|c|c|c|c|c|}
\hline \multirow[t]{2}{*}{ Fresh produce } & \multirow{2}{*}{$\begin{array}{l}\mathrm{PL} \\
\text { treatment } \\
\text { conditions }\end{array}$} & \multicolumn{2}{|l|}{$\mathrm{EC}$} & \multirow{2}{*}{$\begin{array}{l}\text { Order of } \\
\text { treatments }\end{array}$} & \multirow{2}{*}{$\begin{array}{l}\text { Storage } \\
\text { conditions }\end{array}$} & \multirow[t]{2}{*}{ Effect of combined treatments } & \multirow[t]{2}{*}{ Ref. } \\
\hline & & $\begin{array}{l}\text { Film-forming } \\
\text { solutions }\end{array}$ & Method of application & & & & \\
\hline $\begin{array}{l}\text { Fresh green } \\
\text { beans }\end{array}$ & $\begin{array}{l}\text { Fluence of } \\
\begin{array}{l}3-6-12 \\
\mathrm{~J} / \mathrm{cm}^{2} \\
\text { for each } \\
\text { side }\end{array}\end{array}$ & $\begin{array}{l}1 \% \text { chitosan }+ \\
0.05 \% \text { mandarin } \\
\text { EO }\end{array}$ & $\begin{array}{l}\text { Spraying for } 5 \mathrm{~s} \text { on } \\
\text { each side at } 1.4 \times \\
10^{-5} \mathrm{~Pa}\end{array}$ & $\begin{array}{l}\text { 1. Coating } \\
\text { 2. PL }\end{array}$ & $\begin{array}{l}4{ }^{\circ} \mathrm{C} \text { in sterile } \\
\text { pouches }\end{array}$ & $\begin{array}{l}\text { The combination of PL treatment } \\
\text { and bioactive EC did not show } \\
\text { any synergistic or additive } \\
\text { antimicrobial effect against } \\
\text { L. innocua during storage, } \\
\text { with browning spots formation } \\
\text { on the samples. However, } \\
\text { treatment combination did not } \\
\text { affect the samples' firmness } \\
\text { during storage nor the coating } \\
\text { integrity. }\end{array}$ & {$[8]$} \\
\hline Fresh-cut apple & $\begin{array}{l}\text { Fluence of } \\
12 \\
\mathrm{~J} / \mathrm{cm}^{2}\end{array}$ & $\begin{array}{c}0.5 \% \text { gellan gum }+ \\
0.2 \% \text { apple fiber } \\
+0.6 \% \text { glycerol } \\
\left(1^{\text {st }} \text { solution }\right) \\
2 \% \text { calcium } \\
\text { chloride }\left(2^{\text {nd }}\right. \\
\text { solution })\end{array}$ & $\begin{array}{l}\text { Cross-linking dipping } \\
\text { for } 2 \text { min in each } \\
\text { solution, with drip } \\
\text { off for } 1 \text { min } \\
\text { between the two }\end{array}$ & $\begin{array}{l}\text { 1. Coating } \\
\text { 2. } \mathrm{PL}\end{array}$ & $4^{\circ} \mathrm{C}$ in the dark & $\begin{array}{l}\text { The use of coating incorporating } \\
\text { apple fiber followed by PL } \\
\text { treatment reduced softening } \\
\text { and browning and preserved } \\
\text { the antioxidant value of } \\
\text { fresh-cut apples. However, the } \\
\text { use of ECs reduced the extent } \\
\text { of surface decontamination by } \\
\text { PL. }\end{array}$ & {$[262]$} \\
\hline Fresh-cut apple & $\begin{array}{c}\text { Fluence of } \\
12 \\
\mathrm{~J} / \mathrm{cm}^{2}\end{array}$ & $\begin{array}{l}2 \% \text { pectin }+0.7 \% \\
\text { apple fiber }+ \\
1.5 \% \text { glycerol } \\
\left(1^{\text {st }} \text { solution }\right) 2 \% \\
\text { calcium chloride } \\
\left(2^{\text {nd }} \text { solution }\right)\end{array}$ & $\begin{array}{l}\text { Cross-linking dipping } \\
\text { for } 2 \text { min in each } \\
\text { solution, with drip } \\
\text { off for } 1 \text { min } \\
\text { between the two }\end{array}$ & $\begin{array}{l}\text { 1. Coating } \\
\text { 2. PL }\end{array}$ & $4{ }^{\circ} \mathrm{C}$ in the dark & $\begin{array}{l}\text { The combination of both } \\
\text { technologies led to a } \\
\text { significant reduction in the } \\
\text { counts of spoilage } \\
\text { microorganisms and higher } \\
\text { antioxidant activity values, } \\
\text { although an additive effect of } \\
\text { both treatments could not be } \\
\text { observed. }\end{array}$ & {$[263]$} \\
\hline $\begin{array}{r}\text { Fresh-cut } \\
\text { mango }\end{array}$ & $\begin{array}{l}\text { Fluence of } \\
8 \mathrm{~J} / \mathrm{cm}^{2}\end{array}$ & $\begin{array}{l}2 \% \text { sodium alginate } \\
\left(1^{\text {st }} \text { solution }\right) \\
2 \% \text { calcium } \\
\text { chloride }\left(2^{\text {nd }}\right. \\
\text { solution }) \\
2 \% \text { DL-malic acid }\end{array}$ & $\begin{array}{l}\text { Cross-linking dipping } \\
\text { for } 2 \text { min in each } \\
\text { solution } \\
\text { Dipping for } 2 \mathrm{~min}\end{array}$ & $\begin{array}{l}\text { 1. Coating } \\
\text { 2. PL and vice } \\
\text { versa }\end{array}$ & $\begin{array}{l}4^{\circ} \mathrm{C} \text { in } \\
\text { polypropylene } \\
\text { trays }\end{array}$ & $\begin{array}{l}\text { An additive effect on microbial } \\
\text { load reduction by combined } \\
\text { treatments was observed. } \\
\text { Moreover, the order in which } \\
\text { such treatments were } \\
\text { performed played an important } \\
\text { role in fresh-cut mango pres- } \\
\text { ervation. PL treatment follow- } \\
\text { ed by coatings ensured better } \\
\text { quality parameters and micro- } \\
\text { bial stability with minimal } \\
\text { quality deterioration through- } \\
\text { out storage. }\end{array}$ & {$[264]$} \\
\hline $\begin{array}{l}\text { Fresh-cut } \\
\text { cantaloupe } \\
\text { melon }\end{array}$ & $\begin{array}{c}\text { Fluence of } \\
11.7 \\
\mathrm{~J} / \mathrm{cm}^{2}\end{array}$ & $\begin{array}{l}1 \% \text { chitosan }+1 \% \\
\text { glycerol }+ \\
0.025 \% \\
\text { sunflower } \\
1 \% \text { pectin/sodium } \\
\text { alginate }+1 \% \\
\text { glycerol }+ \\
0.025 \% \text { sun- } \\
\text { flower }\left(1^{\text {st }} \text { solu- }\right. \\
\text { tion) } \\
2 \% \text { calcium } \\
\text { chloride }\left(2^{\text {nd }}\right. \\
\text { solution }) \\
0.5 \% \text { gellan gum }+ \\
0.5 \% \text { glycerol }+ \\
0.025 \% \\
\text { sunflower }\left(1^{\text {st }}\right. \\
\text { solution) }\end{array}$ & $\begin{array}{l}\text { Cross-linking dipping } \\
\text { for } 2 \text { min in each } \\
\text { solution, with drip } \\
\text { off for } 1 \text { min } \\
\text { between the two }\end{array}$ & $\begin{array}{l}\text { 1. Coating } \\
\text { 2. PL on a } \\
\text { packaged } \\
\text { product }\end{array}$ & $\begin{array}{l}4^{\circ} \mathrm{C} \text { in a } \\
\text { polypropylene } \\
\text { bag }\end{array}$ & $\begin{array}{l}\text { The combination of pectin, } \\
\text { sodium alginate, and gellan } \\
\text { gum coatings with PL } \\
\text { treatment was effective to } \\
\text { reduce fluid loss and retain } \\
\text { firmness and maintain the } \\
\text { desired headspace gas } \\
\text { composition throughout } \\
\text { storage. Moreover, a } \\
\text { combination of PL treatment } \\
\text { and alginate was the most } \\
\text { effective treatment condition } \\
\text { to extend the shelf life in terms } \\
\text { of microbiological quality. The } \\
\text { sodium alginate coating } \\
\text { adhered well to the surfaces of } \\
\text { samples and significantly } \\
\text { reduced fluid loss and } \\
\text { enhanced firmness compared }\end{array}$ & {$[265]$} \\
\hline
\end{tabular}


Table 3 (continued)

\begin{tabular}{|c|c|c|c|c|c|c|c|}
\hline \multirow[t]{2}{*}{ Fresh produce } & \multirow{2}{*}{$\begin{array}{l}\mathrm{PL} \\
\text { treatment } \\
\text { conditions }\end{array}$} & \multicolumn{2}{|l|}{$\mathrm{EC}$} & \multirow{2}{*}{$\begin{array}{l}\text { Order of } \\
\text { treatments }\end{array}$} & \multirow{2}{*}{$\begin{array}{l}\text { Storage } \\
\text { conditions }\end{array}$} & \multirow[t]{2}{*}{ Effect of combined treatments } & \multirow[t]{2}{*}{ Ref. } \\
\hline & & $\begin{array}{l}\text { Film-forming } \\
\text { solutions }\end{array}$ & Method of application & & & & \\
\hline & & $\begin{array}{l}2 \% \text { calcium } \\
\text { chloride }\left(2^{\text {nd }}\right. \\
\text { solution })\end{array}$ & & & & $\begin{array}{l}\text { to samples treated with PL } \\
\text { alone while retaining its } \\
\text { physicochemical and } \\
\text { nutritional quality. }\end{array}$ & \\
\hline $\begin{array}{r}\text { Fresh-cut } \\
\text { mango }\end{array}$ & $\begin{array}{l}\text { Fluence of } \\
8 \mathrm{~J} / \mathrm{cm}^{2}\end{array}$ & $\begin{array}{l}2 \% \text { sodium alginate } \\
\left(1^{\text {st }} \text { solution }\right) \\
2 \% \text { calcium } \\
\text { chloride }\left(2^{\text {nd }}\right. \\
\text { solution }) \\
2 \% \text { DL-malic acid } \\
\left(3^{\text {rd }} \text { solution }\right)\end{array}$ & $\begin{array}{l}\text { Cross-linking }\left(1^{\text {st }} \text { and }\right. \\
2^{\text {nd }} \text { solutions) and } \\
\text { layer-by-layer coat- } \\
\text { ing deposition by } \\
\text { dipping for } 2 \text { min in } \\
\text { each solution }\end{array}$ & $\begin{array}{l}\text { 1. Coating } \\
\text { 2. PL and vice } \\
\text { versa }\end{array}$ & $\begin{array}{l}4{ }^{\circ} \mathrm{C} \text { in } \\
\text { polypropylene } \\
\text { trays }\end{array}$ & $\begin{array}{l}\text { Both combined treatments seem } \\
\text { to enhance phenolic } \\
\text { compounds content while } \\
\text { preserving both antioxidant } \\
\text { capacity, phenolic compound } \\
\text { content, and color. Moreover, } \\
\text { the combination of coating } \\
\text { followed by PL treatment } \\
\text { enhances mangiferin content } \\
\text { by inducing a stress response } \\
\text { throughout storage days. }\end{array}$ & {$[266]$} \\
\hline $\begin{array}{l}\text { Fresh-cut } \\
\text { cucumber }\end{array}$ & $\begin{array}{c}\text { Fluence of } \\
4-8-12 \\
\mathrm{~J} / \mathrm{cm}^{2}\end{array}$ & $\begin{array}{r}2 \% \text { chitosan }+ \\
0.03-0.08 \% \\
\text { carvacrol EO }\end{array}$ & Dipping for $3 \mathrm{~min}$ & $\begin{array}{l}\text { 1. Coating } \\
\text { 2. PL }\end{array}$ & $\begin{array}{l}25^{\circ} \mathrm{C} \text { in a safety } \\
\text { cabinet }\end{array}$ & $\begin{array}{l}\text { The combination of the two } \\
\text { technologies resulted in a } \\
\text { strong synergistic effect, with } \\
\text { E. coli reduction when more } \\
\text { intense PL treatment was } \\
\text { combined with the coating } \\
\text { suspension containing } 0.08 \% \\
\text { carvacrol. }\end{array}$ & [267] \\
\hline $\begin{array}{l}\text { Fresh-cut } \\
\text { cantaloupe } \\
\text { melon }\end{array}$ & $\begin{array}{c}\text { Fluence of } \\
11.7 \\
\mathrm{~J} / \mathrm{cm}^{2}\end{array}$ & $\begin{array}{l}0-2 \% \text { sodium } \\
\text { alginate }+0-2 \% \\
\text { glycerol }+ \\
0.025 \% \\
\text { sunflower oil }\left(1^{\text {st }}\right. \\
\text { solution) } \\
2 \% \text { calcium } \\
\text { chloride ( } 2^{\text {nd }} \\
\text { solution) }\end{array}$ & $\begin{array}{l}\text { Cross-linking dipping } \\
\text { for } 2 \text { min in each } \\
\text { solution, with drip } \\
\text { off for } 1 \text { min } \\
\text { between the two }\end{array}$ & $\begin{array}{l}\text { 1. Coating } \\
\text { 2. PL on a } \\
\text { packaged } \\
\text { product }\end{array}$ & $4^{\circ} \mathrm{C}$ in a cooler box & $\begin{array}{l}\text { The combined treatment } \\
\text { increases the shelf life in terms } \\
\text { of microbiological quality and } \\
\text { reduces the fluid loss while } \\
\text { maintaining its } \\
\text { physicochemical and } \\
\text { nutritional quality. Therefore, } \\
\text { combined treatment is } \\
\text { necessary due to their } \\
\text { synergistic effect since PL } \\
\text { treatment contributed to the } \\
\text { increased microbiological } \\
\text { quality while coating targeted } \\
\text { on the improvement of } \\
\text { physical quality in fresh-cut } \\
\text { cantaloupe. }\end{array}$ & [268] \\
\hline $\begin{array}{l}\text { Fresh-cut } \\
\quad \text { cantaloupe } \\
\text { melon }\end{array}$ & $\begin{array}{l}\text { Fluence of } \\
\begin{array}{l}11.7 \\
\mathrm{~J} / \mathrm{cm}^{2}\end{array}\end{array}$ & $\begin{array}{l}1.86 \% \text { sodium } \\
\quad \text { alginate }+1.47 \% \\
\text { glycerol }+ \\
0.025 \% \\
\text { sunflower oil }\left(1^{\text {st }}\right. \\
\text { solution }) \\
2 \% \text { calcium } \\
\quad \text { chloride }\left(2^{\text {nd }}\right. \\
\text { solution })\end{array}$ & $\begin{array}{l}\text { Cross-linking dipping } \\
\text { for } 2 \text { min in each } \\
\text { solution, with drip } \\
\text { off for } 1 \text { min } \\
\text { between the two }\end{array}$ & $\begin{array}{l}\text { 1. Coating } \\
\text { 2. PL on a } \\
\text { packaged } \\
\text { product }\end{array}$ & $\begin{array}{l}4{ }^{\circ} \mathrm{C} \text { in a } \\
\text { polypropylene } \\
\text { bag }\end{array}$ & $\begin{array}{l}\text { The combination of alginate } \\
\text { coating with PL treatment } \\
\text { maintains low lactic acid } \\
\text { concentration and retains total } \\
\text { aroma compound } \\
\text { concentration as storage time } \\
\text { increased. Overall, the } \\
\text { combination of alginate } \\
\text { coating and PL treatment was } \\
\text { effective to maintain the } \\
\text { fresh-like sensory quality of } \\
\text { fresh-cut cantaloupes with } \\
\text { minimal changes on sugar } \\
\text { contents, organic acid } \\
\text { contents, and total aroma } \\
\text { compound concentration. }\end{array}$ & {$[269]$} \\
\hline
\end{tabular}

ECs loaded with active compounds protect food products from deteriorative processes, such as oxidation, water loss, and browning, and slow down or inhibit microbial growth, while minimally affecting product appearance. PL treatments 
are fast and extremely effective for surface decontamination and can be used to treat packaged foods. These technologies can be coupled, in a hurdle approach, with the application of PL treatments, either as a preliminary food decontamination process, to reduce the initial microbial load, or after coating application, and even better after food packaging, to inactivate microorganisms contaminating the product after applying the EC. The latter two options are appealing for those products, for which the initial contamination level is not an issue (e.g., fresh-cut fruits and vegetables), and for which the sequence of coating application and subsequent PL treatment might significantly extend the product shelf life.

A fundamental understanding of the possible synergistic or antagonistic effects of EC-PL treatment combinations needs to be better addressed. For example, the effects of PL treatments on the physicochemical properties of the ECs have not been fully elucidated. Positive effects are likely since the UV components of the PL might cause cross-linking reactions in the coating layer, improving its mechanical properties. Also, the interference of ECs, especially if loaded with bioactive compounds, on light transmission through the coating needs to be better understood. If the PL treatment is carried out after coating deposition, an eventual UV shielding effect might be advantageous if the food surface is particularly light-sensitive, for food protection and coating decontamination.

The process complexity and investment costs that the combined use of EC application and PL treatments bring along clearly represent a potential barrier to a wide industrial application. However, the availability on the market of small-scale pulsed light units and the possibility to develop relatively simple batch systems for coating application makes the proposed combined process especially suitable for high value-added products, especially if produced in rural areas, where efficient logistics is not available. The scaling up of the combined process can be also easily predicted, provided that suitable product conveyors, allowing light penetration, and PL systems with flash lamps in series, allowing to supply the right dose and residence time, are designed and set up. Moreover, since it is possible to apply the PL treatments in continuous mode, this makes it feasible to have considerably high product throughputs. To this purpose, some of the techniques for EC application and PL apparatus already in use for PL industrial applications eventually modified ad hoc to process coated fruits and vegetables are already available and could be used for industrial proof-of-concept tests. Once a few industrial applications have been developed, the economic feasibility for larger-scale applications can then be better assessed to make this method for high value-added convenience food preservation a means to satisfy the consumer's demand for milder processes and increased use of natural ingredients while meeting their quality and safety expectations.
Funding Information Open access funding provided by Università degli Studi di Salerno within the CRUI-CARE Agreement. This work was partly supported by the ERA-NET ARIMNet2 Call 2016 with the project "Valorization of Industrial fruits by-products and algae biomass waste: Development of Active Coatings to extend Food shelf life and reduce food losses - VIPACFood (2017-2020)" and by the Italian Ministry of University (MUR) call PRIN 2017 with the project 2017LEPH3M "PANACEA: A technology PlAtform for the sustainable recovery and advanced use of NAnostructured CEllulose from Agro-food residues."

\section{Compliance with Ethical Standards}

Conflict of Interest The authors declare that they have no conflict of interest.

Open Access This article is licensed under a Creative Commons Attribution 4.0 International License, which permits use, sharing, adaptation, distribution and reproduction in any medium or format, as long as you give appropriate credit to the original author(s) and the source, provide a link to the Creative Commons licence, and indicate if changes were made. The images or other third party material in this article are included in the article's Creative Commons licence, unless indicated otherwise in a credit line to the material. If material is not included in the article's Creative Commons licence and your intended use is not permitted by statutory regulation or exceeds the permitted use, you will need to obtain permission directly from the copyright holder. To view a copy of this licence, visit http://creativecommons.org/licenses/by/4.0/.

\section{References}

1. Birmpa A, Sfika V, Vantarakis A (2013) Ultraviolet light and ultrasound as non-thermal treatments for the inactivation of microorganisms in fresh ready-to-eat foods. Int J Food Microbiol 167:96-102

2. Ju J, Xie Y, Guo Y, Cheng Y, Qian H, Yao W (2019) Application of edible coating with essential oil in food preservation. Crit Rev Food Sci Nutr 59:2467-2480

3. Raso J, Barbosa-Cánovas GV (2003) Nonthermal preservation of foods using combined processing techniques. Crit Rev Food Sci Nutr 43:265-285

4. Wang C-Y, Huang H-W, Hsu C-P, Yang BB (2016) Recent advances in food processing using high hydrostatic pressure technology. Crit Rev Food Sci Nutr 56:527-540

5. Cuq B, Gontard N, Guilbert S (1995) Edible films and coatings as active layers. In: Rooney ML (ed) Active food packaging. Springer US, pp 111-142. https://doi.org/10.1007/978-1-46152175-4_5

6. Guilbert S, Gontard N, Cuq B (1995) Technology and applications of edible protective films. Packag Technol Sci 8:339-346

7. Mohammadi A, Hashemi M, Hosseini SM (2015) Chitosan nanoparticles loaded with Cinnamomum zeylanicum essential oil enhance the shelf life of cucumber during cold storage. Postharvest Biol Technol 110:203-213

8. Donsì F, Marchese E, Maresca P, Pataro G, Vu KD, Salmieri S, Lacroix M, Ferrari G (2015) Green beans preservation by combination of a modified chitosan based-coating containing nanoemulsion of mandarin essential oil with high pressure or pulsed light processing. Postharvest Biol Technol 106:21-32

9. Severino R, Vu KD, Donsì F, Salmieri S, Ferrari G, Lacroix M (2014) Antibacterial and physical effects of modified chitosan based-coating containing nanoemulsion of mandarin essential oil 
and three non-thermal treatments against Listeria innocua in green beans. Int J Food Microbiol 191:82-88

10. Chen H, Hu X, Chen E, Wu S, McClements DJ, Liu S, Li B, Li Y (2016) Preparation, characterization, and properties of chitosan films with cinnamaldehyde nanoemulsions. Food Hydrocoll 61: 662-671

11. Leistner L, Gorris LGM (1995) Food preservation by hurdle technology. Trends Food Sci Technol 6:41-46

12. Severino R, Ferrari G, Vu KD, Donsì F, Salmieri S, Lacroix M (2015) Antimicrobial effects of modified chitosan based coating containing nanoemulsion of essential oils, modified atmosphere packaging and gamma irradiation against Escherichia coli O157: H7 and Salmonella typhimurium on green beans. Food Control $50: 215-222$

13. Oms-Oliu G, Martín-Belloso O, Soliva-Fortuny R (2010) Pulsed light treatments for food preservation. A review. Food Bioprocess Technol 3:13-23

14. Li X, Farid M (2016) A review on recent development in nonconventional food sterilization technologies. J Food Eng 182:3345

15. Zink J, Wyrobnik T, Prinz T, Schmid M (2016) Physical, chemical and biochemical modifications of protein-based films and coatings: an extensive review. 17 ISBN 8161491526

16. Krochta JM, Baldwin EA, Hagenmaier RD, Pérez-Gago MB, Hall DJ, Soliva-Fortuny R, Rojas-Grä̈ MA, Martín-Belloso O, de Avena-Bustillos RJ, McHugh TH et al (1994) Edible coatings and films to improve food quality. In: Baldwin EA, Hagenmaier R, Bai J, Krochta JM (eds) . CRC, Boca Raton

17. Moreno MA, Bojorges H, Falcó I, Sánchez G, López-Carballo G, López-Rubio A, Zampini IC, Isla MI, Fabra MJ (2020) Active properties of edible marine polysaccharide-based coatings containing Larrea nitida polyphenols enriched extract. Food Hydrocoll 102:1-11

18. Guitián MV, Ibargurena C, Soriaa MC, Hovanyecz P, Banchio C, CarinaAudisio M (2019) Anti-Listeria monocytogenes effect of bacteriocin-incorporated agar edible coatings applied on cheese. Int Dairy J 97:92-98

19. Hussein Ziedan ES, El Zahaby HM, Maswada HF, El Rafh Zoeir EHA (2018) Agar-agar a promising edible coating agent for management of postharvest diseases and improving banana fruit quality. J Plant Prot Res 58:234-240. https://doi.org/10.24425/122938

20. Dai LL, Zhang J, Cheng F (2020) Cross-linked starch-based edible coating reinforced by starch nanocrystals and its preservation effect on graded Huangguan pears. Food Chem 311:1-9

21. Ferreira DCM, Molina G, Pelissari FM (2020) Effect of edible coating from cassava starch and Babassu flour (Orbignya phalerata) on Brazilian cerrado fruits quality. Food Bioprocess Technol 13:172-179

22. de Vasconcellos Santos Batista D, Reis RC, Almeida JM, Rezende B, Bragança CAD, da Silva F (2020) Edible coatings in post-harvest papaya: impact on physical-chemical and sensory characteristics. J Food Sci Technol 57:274-281

23. Islam MZ, Saha T, Monalisa K, Hoque MM (2019) Effect of starch edible coating on drying characteristics and antioxidant properties of papaya. J Food Meas Charact 13:2951-2960

24. de Oliveira Alves Sena E, Oliveira da Silva PS, de Aragão Batista MC, Sargent SA, de Oliveira LFG Jr, Almeida Castro Pagani A, Gutierrez Carnelossi MA (2019) Calcium application via hydrocooling and edible coating for the conservation and quality of cashew apples. Sci Hortic (Amsterdam) 256:108531. https:// doi.org/10.1016/j.scienta.2019.05.058

25. Arroyo BJ, Bezerra AC, Oliveira LL, Arroyo SJ, Melo EAD, Santos AMP (2020) Antimicrobial active edible coating of alginate and chitosan add $\mathrm{ZnO}$ nanoparticles applied in guavas (Psidium guajava L.). Food Chem 309:125566. https://doi.org/ 10.1016/j.foodchem.2019.125566
26. Fernandes L, Pereira EL, do Céu Fidalgo M, Gomes A, Ramalhosa E (2020) Physicochemical properties and microbial control of chestnuts (Castanea sativa) coated with whey protein isolate, chitosan and alginate during storage. Sci Hortic (Amsterdam) 263:109105. https://doi.org/10.1016/j.scienta. 2019.109105

27. Khanzadi S, Keykhosravy K, Hashemi M, Azizzadeh M (2020) Alginate coarse/nanoemulsions containing Zataria multiflora Boiss essential oil as edible coatings and the impact on microbial quality of trout fillet. Aquac Res 51:873-881. https://doi.org/10. 1111/are. 14418

28. Guerrero A, Ferrero S, Barahona M, Boito B, Lisbinski E, Maggi F, Sañudo C (2019) Effects of active edible coating based on thyme and garlic essential oils on lamb meat shelf life after longterm frozen storage. J Sci Food Agric 100:656-664

29. Tabassum N, Khan MA (2019) Modified atmosphere packaging of fresh-cut papaya using alginate based edible coating: quality evaluation and shelf life study. Sci Hortic (Amsterdam) 259: 108853. https://doi.org/10.1016/j.scienta.2019.108853

30. Morsy NE, Rayan AM (2019) Effect of different edible coatings on biochemical quality and shelf life of apricots (Prunus armenica L. cv Canino). J Food Meas Charact 13:3173-3182

31. Li XY, Du XL, Liu Y, Tong LJ, Wang Q, Li JL (2019) Rhubarb extract incorporated into an alginate-based edible coating for peach preservation. Sci Hortic (Amsterdam) 257:108685. https:// doi.org/10.1016/j.scienta.2019.108685

32. Baswal AK, Dhaliwal HS, Singh Z, Mahajan BVC, Kalia A, Gill KS (2020) Influence of carboxy methylcellulose, chitosan and beeswax coatings on cold storage life and quality of Kinnow mandarin fruit. Sci Hortic (Amsterdam) 260:108887. https://doi.org/ 10.1016/j.scienta.2019.108887

33. Totad MG, Sharma RR, Sethi S, Verma MK (2019) Effect of edible coatings on 'Misty' blueberry (Vaccinium corymbosum) fruits stored at low temperature. Acta Physiol Plant 41:1-7

34. Rikhotso MM, Magwaza LS, Tesfay SZ, Mditshwa A (2019) Evaluating the efficacy of chitosan and CMC incorporated with moringa leaf extracts on reducing peteca spot incidence on 'Eureka' lemon. J Food Sci Technol 56:5074-5086

35. Ehteshami S, Abdollahi F, Ramezanian A, Dastjerdi AM, Rahimzadeh M (2019) Enhanced chilling tolerance of pomegranate fruit by edible coatings combined with malic and oxalic acid treatments. Sci Hortic (Amsterdam) 250:388-398

36. Tumbarski Y, Nikolova R, Petkova N, Ivanov I, Lante A (2019) Biopreservation of fresh strawberries by carboxymethyl cellulose edible coatings enriched with a bacteriocin from Bacillus methylotrophicus BM47. Food Technol Biotechnol 57:230-237

37. Ghadermazi R, Hamdipour S, Sadeghi K, Ghadermazi R, Khosrowshahi Asl A (2019) Effect of various additives on the properties of the films and coatings derived from hydroxypropyl methylcellulose - a review. Food Sci Nutr 7:3363-3377

38. Vishwasrao C, Ananthanarayan L (2016) Postharvest shelf-life extension of pink guavas (Psidium guajava L.) using HPMCbased edible surface coatings. J Food Sci Technol 53:1966-1974

39. Xiong Y, Chen M, Warner RD, Fang Z (2020) Incorporating nisin and grape seed extract in chitosan-gelatine edible coating and its effect on cold storage of fresh pork. Food Control 110:107018

40. Tokatlı K, Demirdöven A (2020) Effects of chitosan edible film coatings on the physicochemical and microbiological qualities of sweet cherry (Prunus avium L.). Sci Hortic (Amsterdam) 259: 108656. https://doi.org/10.1016/j.scienta.2019.108656

41. Yan J, Luo Z, Ban Z, Lu H, Li D, Yang D, Aghdam MS, Li L (2019) The effect of the layer-by-layer (LBL) edible coating on strawberry quality and metabolites during storage. Postharvest Biol Technol 147:29-38

42. Falcó I, Randazzo W, Sánchez G, López-Rubio A, Fabra MJ (2019) On the use of carrageenan matrices for the development 
of antiviral edible coatings of interest in berries. Food Hydrocoll 92:74-85

43. Volpe MG, Coccia E, Siano F, Di Stasio M, Paolucci M (2019) Rapid evaluation methods for quality of trout (Oncorhynchus mykiss) fresh fillet preserved in an active edible coating. Foods 8:113

44. Ruelas-Chacon X, Contreras-Esquivel JC, Montañez J, AguileraCarbo AF, Reyes-Vega ML, Peralta-Rodriguez RD, SanchézBrambila G (2017) Guar gum as an edible coating for enhancing shelf-life and improving postharvest quality of roma tomato (Solanum lycopersicum L.). J Food Qual 2017:8608304

45. Naeem A, Abbas T, Ali TM, Hasnain A (2018) Effect of antioxidant and antibacterial properties of guar gum coating containing spice extracts and its application on tomatoes (Solanum lycopersicum L.). J Food Meas Charact 12:2725-2734

46. Naeem A, Abbas T, Ali TM, Hasnain A (2018) Effect of guar gum coatings containing essential oils on shelf life and nutritional quality of green-unripe mangoes during low temperature storage. Int J Biol Macromol 113:403-410

47. Daisy LL, Nduko JM, Joseph WM, Richard SM (2020) Effect of edible gum Arabic coating on the shelf life and quality of mangoes (Mangifera indica) during storage. J Food Sci Technol 57:79-85

48. Tahir HE, Zhihua L, Mahunu GK, Xiaobo Z, Arslan M, Xiaowei H, Yang Z, Mariod AA (2020) Effect of gum arabic edible coating incorporated with African baobab pulp extract on postharvest quality of cold stored blueberries. Food Sci Biotechnol 29:217226

49. Yang Z, Zou X, Li Z, Huang X, Zhai X, Zhang W, Shi J, Tahir HE (2019) Improved postharvest quality of cold stored blueberry by edible coating based on composite gum Arabic/Roselle extract. Food Bioprocess Technol 12:1537-1547

50. Etemadipoor R, Ramezanian A, Mirzaalian Dastjerdi A, Shamili M (2019) The potential of gum arabic enriched with cinnamon essential oil for improving the qualitative characteristics and storability of guava (Psidium guajava L.) fruit. Sci Hortic (Amsterdam) 251:101-107

51. Golly MK, Ma H, Sarpong F, Dotse BP, Oteng-Darko P, Dong Y (2019) Shelf-life extension of grape (Pinot noir) by xanthan gum enriched with ascorbic and citric acid during cold temperature storage. J Food Sci Technol 56:4867-4878

52. García-Betanzos CI, Hernández-Sánchez H, Bernal-Couoh TF, Quintanar-Guerrero D, de la Zambrano-Zaragoza ML (2017) Physicochemical, total phenols and pectin methylesterase changes on quality maintenance on guava fruit (Psidium guajava L.) coated with candeuba wax solid lipid nanoparticles-xanthan gum. Food Res Int 101:218-227

53. Danalache F, Carvalho CY, Alves VD, Moldão-Martins M, Mata P (2016) Optimisation of gellan gum edible coating for ready-toeat mango (Mangifera indica L.) bars. Int J Biol Macromol 84:4353

54. Moreira MR, Cassani L, Martín-Belloso O, Soliva-Fortuny R (2015) Effects of polysaccharide-based edible coatings enriched with dietary fiber on quality attributes of fresh-cut apples. J Food Sci Technol 52:7795-7805

55. Maftoonazad N, Ramaswamy HS (2019) Application and evaluation of a pectin-based edible coating process for quality change kinetics and shelf-life extension of lime fruit (Citrus aurantifolium). Coatings 9:285

56. Nisar T, Yang X, Alim A, Iqbal M, Wang ZC, Guo Y (2019) Physicochemical responses and microbiological changes of bream (Megalobrama ambycephala) to pectin based coatings enriched with clove essential oil during refrigeration. Int J Biol Macromol 124:1156-1166

57. Muñoz-Labrador A, Moreno R, Villamiel M, Montilla A (2018) Preparation of citrus pectin gels by power ultrasound and its application as an edible coating in strawberries. J Sci Food Agric 98:4866-4875

58. Radi M, Akhavan-Darabi S, Akhavan HR, Amiri S (2018) The use of orange peel essential oil microemulsion and nanoemulsion in pectin-based coating to extend the shelf life of fresh-cut orange. J Food Process Preserv 42:1-9

59. Abdallah MR, Mohamed MA, Mohamed H, Emara MT (2018) Application of alginate and gelatin-based edible coating materials as alternatives to traditional coating for improving the quality of pastirma. Food Sci Biotechnol 27:1589-1597

60. Tao F, Shi C, Cui Y (2018) Preparation and physicochemistry properties of smart edible films based on gelatin-starch nanoparticles. J Sci Food Agric 98:5470-5478

61. Bonnaillie LM, Zhang H, Akkurt S, Yam KL, Tomasula PM (2014) Casein films: the effects of formulation, environmental conditions and the addition of citric pectin on the structure and mechanical properties. Polymers (Basel) 6:2018-2036

62. Yangilar F, Oğuzhan Yildiz P (2016) Casein/natamycin edible films efficiency for controlling mould growth and on microbiological, chemical and sensory properties during the ripening of Kashar cheese. J Sci Food Agric 96:2328-2336

63. Ulutasdemir T, Cagri-Mehmetoglu A (2019) Effects of edible coating containing Williopsis saturnus var. saturnus on fungal growth and aflatoxin production by Aspergillus flavus in peanuts. J Food Saf 39:1-9

64. Galus S, Lenart A (2019) Optical, mechanical, and moisture sorption properties of whey protein edible films. J Food Process Eng 42:1-10

65. Karaminia A, Mousavi M, Askari G (2019) Development of novel active coating from Sagez and Sagez-zein to increase the shelf life of sweet lemon ( Citrus limetta ). J Food Bioprocess Eng 2:41-48

66. Mayeli M, Mehdizadeh T, Tajik H, Esmaeli F, Langroodi AM (2019) Combined impacts of zein coating enriched with methanolic and ethanolic extracts of sour orange peel and vacuum packing on the shelf life of refrigerated rainbow trout. Flavour Fragr J 34: 460-470

67. Moradi M, Tajik H, Razavi Rohani SM, Mahmoudian A (2016) Antioxidant and antimicrobial effects of zein edible film impregnated with Zataria multiflora Boiss. essential oil and monolaurin. LWT Food Sci Technol 72:37-43

68. Kavas N, Kavas G (2016) Physical-chemical and antimicrobial properties of egg white protein powder films incorporated with orange essential oil on kashar cheese. Food Sci Technol 36:672678

69. González A, Barrera GN, Galimberti PI, Ribotta PD, Alvarez Igarzabal CI (2019) Development of edible films prepared by soy protein and the galactomannan fraction extracted from Gleditsia triacanthos (Fabaceae) seed. Food Hydrocoll 97:105227

70. Xue F, Gu Y, Wang Y, Li C, Adhikari B (2019) Encapsulation of essential oil in emulsion based edible films prepared by soy protein isolate-gum acacia conjugates. Food Hydrocoll 96:178-189

71. Miranda M, Gozalbo AM, Sun X, Plotto A, Bai J, Assis OBG, Ferreira MD, Baldwin E (2019) Effect of mono and bilayer of carnauba wax based nanoemulsion. In: SIAGRO 2019 Simpósio Nacional de Instrumentação Agropecuária, pp 705-709

72. Nasrin TAA, Atiqur AM, Arfin MS, Islam MN, Ullah MA (2019) Effect of novel coconut oil and beeswax edible coating on postharvest quality of lemon at ambient storage. J Agric Food Res 2: 100019

73. Guimarães JER, de la Fuente B, Pérez-Gago MB, Andradas C, Carbó R, Mattiuz BH, Palou L (2019) Antifungal activity of GRAS salts against Lasiodiplodia theobromae in vitro and as ingredients of hydroxypropyl methylcellulose-lipid composite edible coatings to control Diplodia stem-end rot and maintain postharvest quality of citrus fruit. Int J Food Microbiol 301:9-18 
74. Huang Q, Qian X, Jiang T, Zheng X (2019) Effect of chitosan and guar gum based composite edible coating on quality of mushroom (Lentinus edodes) during postharvest storage. Sci Hortic (Amsterdam) 253:382-389

75. Klangmuang P, Sothornvit R (2018) Active hydroxypropyl methylcellulose-based composite coating powder to maintain the quality of fresh mango. LWT 91:541-548

76. Oregel-Zamudio E, Angoa-Pérez MV, Oyoque-Salcedo G, Aguilar-González CN, Mena-Violante HG (2017) Effect of candelilla wax edible coatings combined with biocontrol bacteria on strawberry quality during the shelf-life. Sci Hortic (Amsterdam) 214:273-279

77. Perumalla AVS, Hettiarachchy NS (2011) Green tea and grape seed extracts - potential applications in food safety and quality. Food Res Int 44:827-839

78. Silva-Weiss A, Ihl M, Sobral PJA, Gómez-Guillén MC, Bifani V (2013) Natural additives in bioactive edible films and coatings: functionality and applications in foods. Food Eng Rev 5:200-216

79. Maringgal B, Hashim N, Mohamed Amin Tawakkal IS, Muda Mohamed MT (2020) Recent advance in edible coating and its effect on fresh/fresh-cut fruits quality. Trends Food Sci Technol 96:253-267

80. Guo MQ, Hu X, Wang C, Ai L (2017) Polysaccharides: structure and solubility. In: Xu Z (ed) Solubility of polysaccharides. IntechOpen, pp 7-21. https://doi.org/10.5772/intechopen.71570

81. Dehghani S, Hosseini SV, Regenstein JM (2018) Edible films and coatings in seafood preservation: a review. Food Chem 240:505513

82. Bourtoom T (2008) Edible films and coatings: characteristics and properties. Int Food Res J 15:237-248

83. Chakravartula SSN, Soccio M, Lotti N, Balestra F, Dalla Rosa M, Siracusa V (2019) Characterization of composite edible films based on pectin/alginate/whey protein concentrate. Materials (Basel) 12:1-19

84. Li T, Li J, Hu W, Li X (2013) Quality enhancement in refrigerated red drum (Sciaenops ocellatus) fillets using chitosan coatings containing natural preservatives. Food Chem 138:821-826

85. Cazon P, Velazquez GA, Ramirez J, Vazquez M (2017) Polysaccharide-based films and coatings for food packaging : a review. Food Hydrocoll 68:136-148

86. Lin D, Zhao Y (2007) Innovations in the development and application of edible coatings for fresh and minimally processed fruits and vegetables. Compr Rev Food Sci Food Saf 6:60-75

87. Azeredo HMC, Waldron KW (2016) Crosslinking in polysaccharide and protein films and coatings for food contact - a review. Trends Food Sci Technol 52:109-122

88. Weinberger R (2000) Size separations in capillary gels and polymer networks. In: Weinberger R (ed) Practical capillary electrophoresis. Academic Press, pp 245-292

89. Linnhoff B, Hindmarsh E (1983) The pinch design method for heat exchanger networks. Chem Eng Sci 38:745-763

90. Guo Q, Paliy M, Kobe B, Trebicky T, Suhan N, Arsenault G, Ferrari L, Yang J (2015) Characterization of cross-linking depth for thin polymeric films using atomic force microscopy. J Appl Polym Sci 132:6-11

91. Balaguer MP, Gómez-Estaca J, Gavara R, Hernandez-Munoz P (2011) Functional properties of bioplastics made from wheat gliadins with cinnamaldehyde. J Agric Food Chem 59:6689-6695

92. Bigi A, Cojazzi G, Panzavolta S, Rubini K, Roveri N (2001) Mechanical and thermal properties of gelatin films at different degrees of glutaraldehyde crosslinking. Biomaterials 22:763-768

93. Rimdusit S, Jingjid S, Damrongsakkul S, Tiptipakorn S, Takeichi $\mathrm{T}$ (2008) Biodegradability and property characterizations of methyl cellulose: effect of nanocompositing and chemical crosslinking. Carbohydr Polym 72:444-455
94. Tripathi S, Mehrotra GK, Dutta PK (2009) Physicochemical and bioactivity of cross-linked chitosan-PVA film for food packaging applications. Int J Biol Macromol 45:372-376

95. Yeng CM, Husseinsyah S, Ting SS (2013) Chitosan/corn cob biocomposite films by cross-linking with glutaraldehyde. BioResources 8:2910-2923

96. da Silva MA, Bierhalz ACK, Kieckbusch TG (2009) Alginate and pectin composite films crosslinked with $\mathrm{Ca} 2+$ ions: effect of the plasticizer concentration. Carbohydr Polym 77:736-742

97. Benavides S, Villalobos-Carvajal R, Reyes JE (2012) Physical, mechanical and antibacterial properties of alginate film: effect of the crosslinking degree and oregano essential oil concentration. J Food Eng 110:232-239

98. Bierhalz ACK, da Silva MA, Braga MEM, Sousa HJC, Kieckbusch TG (2014) Effect of calcium and/or barium crosslinking on the physical and antimicrobial properties of natamycin-loaded alginate films. LWT Food Sci Technol 57: 494-501

99. Galietta G, Di Gioia L, Guilbert S, Cuq B (1998) Mechanical and Thermomechanical properties of films based on whey proteins as affected by plasticizer and crosslinking agents. J Dairy Sci 81: 3123-3130

100. Reddy N, Yang Y (2010) Citric acid cross-linking of starch films. Food Chem 118:702-711

101. Shi R, Bi J, Zhang Z, Zhu A, Chen D, Zhou X, Zhang L, Tian W (2008) The effect of citric acid on the structural properties and cytotoxicity of the polyvinyl alcohol/starch films when molding at high temperature. Carbohydr Polym 74:763-770

102. Coma V, Sebti I, Pardon P, Pichavant FH, Deschamps A (2002) Film properties from crosslinking of cellulosic derivatives with a polyfunctional carboxylic acid. Carbohydr Polym 51:265-271

103. Azeredo HMC, Kontou-Vrettou C, Moates GK, Wellner N, Cross K, Pereira PHF, Waldron KW (2015) Wheat straw hemicellulose films as affected by citric acid. Food Hydrocoll 50:1-6

104. Rivero S, García MA, Pinotti A (2010) Crosslinking capacity of tannic acid in plasticized chitosan films. Carbohydr Polym 82: 270-276

105. Cao N, Fu Y, He J (2007) Mechanical properties of gelatin films cross-linked, respectively, by ferulic acid and tannin acid. Food Hydrocoll 21:575-584

106. Banker GS (1966) Film coating theory and practice. J Pharm Sci 55:81-89

107. Gontard N, Guilbert S, Cuq J (1993) L Water and glycerol as plasticizers affect mechanical and water vapor barrier properties of an edible wheat gluten film. J Food Sci 58:206-211

108. Myllärinen P, Partanen R, Seppälä J, Forssell P (2002) Effect of glycerol on behaviour of amylose and amylopectin films. Carbohydr Polym 50:355-361

109. Barreto PLM, Pires ATN, Soldi V (2003) Thermal degradation of edible films based on milk proteins and gelatin in inert atmosphere. Polym Degrad Stab 79:147-152

110. Rojas-Graü MA, Tapia MS, Martín-Belloso O (2008) Using polysaccharide-based edible coatings to maintain quality of fresh-cut Fuji apples. LWT Food Sci Technol 41:139-147

111. Skurtys O, Acevedo C, Pedreschi F, Enronoe J, Osorio F, Aguilera JM (2010) Food hydrocolloid edible films and coatings. Nova Science Publishers Inc, US

112. Sothornvit R, Krochta JM (2005) Plasticizers in edible films and coatings ISBN 9780123116321

113. Khairunnisa S, Rostini I (2018) The effect of glycerol concentration as a plasticizer on edible films made from alginate towards its physical characteristic. World Sci News 112:130-141

114. Murrieta-Martínez C, Soto-Valdez H, Pacheco-Aguilar R, TorresArreola W, Rodríguez-Felix F, Ramírez-Wong B, SantacruzOrtega H, Santos-Sauceda I, Olibarría-Rodríguez G, MárquezRíos E (2019) Effect of different polyalcohols as plasticizers on 
the functional properties of squid protein film (Dosidicus Gigas). Coatings 9:1-12

115. Pavlath AE, Orts W (2009) Edible films and coatings : why, what, and how ? In: Embuscado ME, Huber KC (eds) Edible films and coatings for food applications. Springer Science + Business Media: Western Regional Research Center, ARS, USDA, Albany, pp 1-23 ISBN 9780387928241

116. Choi WY, Park HJ, Ahn DJ, Lee J, Lee CY (2002) Wettability of chitosan coating solution on ' Fuji' apple skin. J Food Sci 67:3-7

117. Lin SY, Krochta JM (2006) Whey protein coating efficiency on mechanically roughened hydrophobic peanut surfaces. J Food Sci 71:270-275

118. Parreidt TS, Schott M, Schmid M, Müller K (2018) Effect of presence and concentration of plasticizers, vegetable oils, and surfactants on the properties of sodium-alginate-based edible coatings. Int J Mol Sci 19:1-21

119. Shchipunov YA, Schmiedel P (1996) Phase behavior of lecithin at the oil/water interface. Langmuir 12:6443-6445

120. U.S. FDA food additives permitted for direct addition to food for human consumption. CFR - Code Fed. Regul. Title 21, Vol. 3, Part 172 2019, 21CFR172

121. Aloui H, Khwaldia K (2016) Natural antimicrobial edible coatings for microbial safety and food quality enhancement. Compr Rev Food Sci Food Saf 15:1080-1103

122. Shahidi F (2000) Antioxidants in food and food antioxidants. Nahrung - Food 44:158-163

123. Martinez MV, Whitaker JR (1995) The biochemistry and control of enzymatic browning. Trends Food Sci Technol 6:195-200

124. Dong X, Wrolstad RE, Sugar D (2000) Extending shelf life of fresh-cut pears. J Food Sci 65:181-186

125. Rocha AMCN, Morais AMMB (2002) Polyphenoloxidase activity and total phenolic content as related to browning of minimally processed "Jonagored" apple. J Sci Food Agric 82:120-126

126. Gontard N, Guilbert S (1994) Bio-packaging: technology and properties of edible and/or biodegradable material of agricultural origin. In: Mathlouthi M (ed) Food packaging and preservation, Springer, Boston, pp 159-181. https://doi.org/10.1007/978-14615-2173-0 9

127. Fathi M, Vinceković M, Jurić S, Viskić M, Režek Jambrak A, Donsì F (2019) Food-grade colloidal systems for the delivery of essential oils. Food Rev Int (AoP). https://doi.org/10.1080/ 87559129.2019.1687514

128. Burt S (2004) Essential oils: their antibacterial properties and potential applications in foods-a review. Int J Food Microbiol 94: 223-253

129. Bakkali F, Averbeck S, Averbeck D, Idaomar M (2008) Biological effects of essential oils - a review. Food Chem Toxicol 46:446-475

130. Seow YX, Yeo CR, Chung HL, Yuk H-G (2014) Plant essential oils as active antimicrobial agents. Crit Rev Food Sci Nutr 54: 625-644

131. Donsì F, Ferrari G (2016) Essential oil nanoemulsions as antimicrobial agents in food. J Biotechnol 233:106-120

132. Acevedo-Fani A, Salvia-Trujillo L, Rojas-Grau MA, MartinBelloso O (2015) Edible films from essential-oil-loaded nanoemulsions: physicochemical characterization and antimicrobial properties. Food Hydrocoll 47:168-177

133. Salvia-Trujillo L, Rojas-Grau MA, Soliva-Fortuny R, MartinBelloso O (2015) Use of antimicrobial nanoemulsions as edible coatings: Impact on safety and quality attributes of fresh-cut Fuji apples. Postharvest Biol Technol 105:8-16

134. Taştan Ö, Ferrari G, Baysal T, Donsì F (2016) Understanding the effect of formulation on functionality of modified chitosan films containing carvacrol nanoemulsions. Food Hydrocoll 61:756-771

135. Dhall RK (2013) Advances in edible coatings for fresh fruits and vegetables: a review. Crit Rev Food Sci Nutr 53:435-450
136. Bouarab Chibane L, Degraeve P, Ferhout H, Bouajila J, Oulahal N (2019) Plant antimicrobial polyphenols as potential natural food preservatives. J Sci Food Agric 99:1457-1474

137. Mei J, Ma X, Xie J (2019) Review on natural preservatives for extending fish shelf life. Foods 8:490

138. Rasouli M, Koushesh Saba M, Ramezanian A (2019) Inhibitory effect of salicylic acid and Aloe vera gel edible coating on microbial load and chilling injury of orange fruit. Sci Hortic (Amsterdam) 247:27-34

139. Sicari V, Loizzo MR, Pellicanò TM, Giuffrè AM, Poiana M (2020) Evaluation of Aloe arborescens gel as new coating to maintain the organoleptic and functional properties of strawberry (Fragaria $\times$ ananassa cv. Cadonga) fruits. Int J Food Sci Technol $55: 861-870$

140. Nourozi F, Sayyari M (2020) Enrichment of Aloe vera gel with basil seed mucilage preserve bioactive compounds and postharvest quality of apricot fruits. Sci Hortic (Amsterdam) 262:109041

141. Parven A, Sarker MR, Megharaj M, Md. Meftaul I (2020) Prolonging the shelf life of papaya (Carica papaya L.) using Aloe vera gel at ambient temperature. Sci Hortic (Amsterdam) 265:109228

142. Yang X, Zhou Y, Wang B, Wang F, Han P, Li L (2019) Tartary buckwheat extract and chitosan coated tilapia (Oreochromis niloticus) fillets determine their shelf life. J Food Sci 84:1288 1296

143. Zam W (2019) Effect of alginate and chitosan edible coating enriched with olive leaves extract on the shelf life of sweet cherries (Prunus avium L.). J Food Qual 2019:8192964

144. Aghofack-Nguemezi J, Hoffmann T, Schwab W (2019) Effects of bio-based coatings on the ripening and quality attributes of tomato (Solanum lycopersicum) fruits. J Sci Food Agric 99:1842-1849

145. Drewnowski A, Gomez-Carneros C (2000) Bitter taste, phytonutrients, and the consumer: a review. Am J Clin Nutr 72: 1424-1435

146. Pina-Pérez MC, Rivas A, Martínez A, Rodrigo D (2017) Antimicrobial potential of macro and microalgae against pathogenic and spoilage microorganisms in food. Food Chem 235:34 44

147. Rico D, Barcenilla B, Meabe A, González C, Martín-Diana AB (2019) Mechanical properties and quality parameters of chitosanedible algae (Palmaria palmata) on ready-to-eat strawberries. J Sci Food Agric 99:2910-2921

148. Luo P, Li F, Liu H, Yang X, Duan Z (2020) Effect of fucoidanbased edible coating on antioxidant degradation kinetics in strawberry fruit during cold storage. J Food Process Preserv 44(4): e14381

149. Tikhonov VE, Stepnova EA, Babak VG, Yamskov IA, PalmaGuerrero J, Jansson H-B, Lopez-Llorca LV, Salinas J, Gerasimenko DV, Avdienko ID et al (2005) Bactericidal and antifungal activities of a low molecular weight chitosan and its $\mathrm{N}-/$ 2(3)-(dodec-2-enyl)succinoyl/-derivatives. Elsevier 64:66-72

150. Alishahi A, Aïder M (2012) Applications of chitosan in the seafood industry and aquaculture: a review. Food Bioprocess Technol 5:817-830

151. Dutta PK, Tripathi S, Mehrotra GK, Dutta J (2009) Perspectives for chitosan based antimicrobial films in food applications. Food Chem 114:1173-1182

152. Poverenov E, Arnon-Rips H, Zaitsev Y, Bar V, Danay O, Horev B, Bilbao-Sainz C, McHugh T, Rodov V (2018) Potential of chitosan from mushroom waste to enhance quality and storability of fresh-cut melons. Food Chem 268:233-241

153. Rorrer LG, Antonio Torres J, Durst R, Kelly C, Gale D, Maddux B, Ozkan A (2016) The potential of a diatom-based photosynthetic biorefinery for biofuels and valued co-products. Curr Biotechnol 5:237-248 
154. LeDuff P, Rorrer GL (2019) Formation of extracellular $\beta$-chitin nanofibers during batch cultivation of marine diatom Cyclotella sp. at silicon limitation. J Appl Phycol 31:3479-3490

155. Ercan D, Demirci A (2016) Recent advances for the production and recovery methods of lysozyme. Crit Rev Biotechnol 36:10781088

156. Barbiroli A, Bonomi F, Capretti G, Iametti S, Manzoni M, Piergiovanni L, Rollini M (2012) Antimicrobial activity of lysozyme and lactoferrin incorporated in cellulose-based food packaging. Food Control 26:387-392

157. Rostami H, Abbaszadeh S, Shokri S (2017) Combined effects of lactoperoxidase system-whey protein coating and modified atmosphere packaging on the microbiological, chemical and sensory attributes of Pike-Perch fillets. J Food Sci Technol 54:3243-3250

158. Jasour MS, Ehsani A, Mehryar L, Naghibi SS (2015) Chitosan coating incorporated with the lactoperoxidase system: an active edible coating for fish preservation. J Sci Food Agric 95:13731378

159. Chaves López C, Serio A, Montalvo C, Ramirez C, Peréz Álvarez JA, Paparella A, Mastrocola D, Martuscelli M (2017) Effect of nisin on biogenic amines and shelf life of vacuum packaged rainbow trout (Oncorhynchus mykiss) fillets. J Food Sci Technol 54: 3268-3277

160. Wu T, Wu C, Fang Z, Ma X, Chen S, Hu Y (2017) Effect of chitosan microcapsules loaded with nisin on the preservation of small yellow croaker. Food Control 79:317-324

161. García-Cayuela T, Requena T, Martínez-Cuesta MC, Peláez C (2017) Rapid detection of Lactococcus lactis isolates producing the lantibiotics nisin, lacticin 481 and lacticin 3147 using MALDITOF MS. J Microbiol Methods 139:138-142

162. Papagianni M, Anastasiadou S (2009) Pediocins: the bacteriocins of pediococci. Sources, production, properties and applications. Microb Cell Factories 8:3

163. Fernández-Cruz ML, Martín-Cabrejas I, Pérez-del Palacio J, Gaya P, Díaz-Navarro C, Navas JM, Medina M, Arqués JL (2016) In vitro toxicity of reuterin, a potential food biopreservative. Food Chem Toxicol 96:155-159

164. Mannozzi C, Tylewicz U, Chinnici F, Siroli L, Rocculi P, Dalla Rosa M, Romani S (2018) Effects of chitosan based coatings enriched with procyanidin by-product on quality of fresh blueberries during storage. Food Chem 251:18-24

165. Abu-Shama HS, Abou-Zaid FOF, El-Sayed EZ (2020) Effect of using edible coatings on fruit quality of Barhi date cultivar. Sci Hortic (Amsterdam) 265:109262

166. Reyes-Avalos MC, Minjares-Fuentes R, Femenia A, ContrerasEsquivel JC, Quintero-Ramos A, Esparza-Rivera JR, MezaVelázquez JA (2019) Application of an alginate-chitosan edible film on figs (Ficus carica): effect on bioactive compounds and antioxidant capacity. Food Bioprocess Technol 12:499-511

167. Ahmed A, Ali SW, Imran A, Afzaal M, Arshad MS, Nadeem M, Mubeen Z, Ikram A (2020) Formulation of date pit oil-based edible wax coating for extending the storage stability of guava fruit. J Food Process Preserv 44

168. Fortunati E, Giovanale G, Luzi F, Mazzaglia A, Kenny J, Torre L, Balestra G (2017) Effective postharvest preservation of kiwifruit and romaine lettuce with a chitosan hydrochloride coating. Coatings 7:196

169. Jiao W, Shu C, Li X, Cao J, Fan X, Jiang W (2019) Preparation of a chitosan-chlorogenic acid conjugate and its application as edible coating in postharvest preservation of peach fruit. Postharvest Biol Technol 154:129-136

170. Pavinatto A, de Almeida Mattos AV, Malpass ACG, Okura MH, Balogh DT, Sanfelice RC (2019) Coating with chitosan-based edible films for mechanical/biological protection of strawberries. Int J Biol Macromol 151:1004-1011
171. Cakmak H, Kumcuoglu S, Tavman S (2019) Electrospray coating of minimally processed strawberries and evaluation of the shelflife quality properties. J Food Process Eng 42(5):e13082

172. Severino R, Vu KD, Donsì F, Salmieri S, Ferrari G, Lacroix M (2014) Antimicrobial effects of different combined non-thermal treatments against Listeria monocytogenes in broccoli florets. J Food Eng 124:1-10

173. Kowalczyk D, Kordowska-Wiater M, Kałwa K, Skrzypek T, Sikora M, Łupina K (2019) Physiological, qualitative, and microbiological changes of minimally processed Brussels sprouts in response to coating with carboxymethyl cellulose/candelilla wax emulsion. J Food Process Preserv 43(8):e14004

174. Sessa M, Ferrari G, Donsì F (2015) Novel edible coating containing essential oil nanoemulsions to prolong the shelf life of vegetable products. Chem Eng Trans 43:55-60

175. Pacaphol K, Seraypheap K, Aht-Ong D (2019) Development and application of nanofibrillated cellulose coating for shelf life extension of fresh-cut vegetable during postharvest storage. Carbohydr Polym 224:115167

176. Sucheta, Chaturvedi K, Sharma N, Yadav SK (2019) Composite edible coatings from commercial pectin, corn flour and beetroot powder minimize post-harvest decay, reduces ripening and improves sensory liking of tomatoes. Int J Biol Macromol 133: 284-293

177. Sarengaowa, Hu W, Feng K, Xiu Z, Jiang A, Lao Y (2019) Efficacy of thyme oil-alginate-based coating in reducing foodborne pathogens on fresh-cut apples. Int J Food Sci Technol 54:3128-3137

178. Sarengaowa, Hu W, Feng K, Xiu Z, Jiang A, Lao Y (2019) Thyme oil alginate-based edible coatings inhibit growth of pathogenic microorganisms spoiling fresh-cut cantaloupe. Food Biosci 32: 100467

179. Arnon-Rips H, Porat R, Poverenov E (2019) Enhancement of agricultural produce quality and storability using citral-based edible coatings; the valuable effect of nano-emulsification in a solidstate delivery on fresh-cut melons model. Food Chem 277:205212

180. Olawuyi IF, Park JJ, Lee JJ, Lee WY (2019) Combined effect of chitosan coating and modified atmosphere packaging on fresh-cut cucumber. Food Sci Nutr 7:1043-1052

181. Rizzo V, Lombardo S, Pandino G, Barbagallo RN, Mazzaglia A, Restuccia C, Mauromicale G, Muratore G (2019) Shelf-life study of ready-to-cook slices of globe artichoke 'Spinoso sardo': effects of anti-browning solutions and edible coating enriched with Foeniculum vulgare essential oil. J Sci Food Agric 99:5219-5228

182. Lara GR, Uemura K, Khalid N, Kobayashi I, Takahashi C, Nakajima M, Neves MA (2020) Layer-by-layer electrostatic deposition of edible coatings for enhancing the storage stability of fresh-cut lotus root (Nelumbo nucifera). Food Bioprocess Technol 13:722-726

183. Sharma L, Saini CS, Sharma HK, Sandhu KS (2019) Biocomposite edible coatings based on cross linked-sesame protein and mango puree for the shelf life stability of fresh-cut mango fruit. J Food Process Eng 42

184. Prakash A, Baskaran R, Vadivel V (2020) Citral nanoemulsion incorporated edible coating to extend the shelf life of fresh cut pineapples. LWT 118:108851

185. Otero-Tuárez V, Carrión-Granda X, Fernández-Pan I, Fernández T, Maté JI (2019) Combined effect of antimicrobial edible coatings with reduction of initial microbial load on the shelf-life of fresh hake (Merluccius merluccius) medallions. Int J Food Sci Technol 54:835-843

186. Maghami M, Motalebi AA, Anvar SAA (2019) Influence of chitosan nanoparticles and fennel essential oils (Foeniculum vulgare) on the shelf life of Huso fish fillets during the storage. Food Sci Nutr 7:3030-3041 
187. Bazargani-Gilani B, Pajohi-Alamoti M (2020) The effects of incorporated resveratrol in edible coating based on sodium alginate on the refrigerated trout (Oncorhynchus mykiss) fillets' sensorial and physicochemical features. Food Sci Biotechnol 29:207-216

188. Alak G, Guler K, Ucar A, Parlak V, Kocaman EM, Yanık T, Atamanalp M (2019) Quinoa as polymer in edible films with essential oil: effects on rainbow trout fillets shelf life. J Food Process Preserv 43:e14268

189. Cardoso GP, Dutra MP, Fontes PR, de Lemos Souza Ramos A, de Miranda Gomide LA, Ramos EM (2016) Selection of a chitosan gelatin-based edible coating for color preservation of beef in retail display. Meat Sci 114:85-94

190. Duran A, Kahve HI (2020) The effect of chitosan coating and vacuum packaging on the microbiological and chemical properties of beef. Meat Sci 162

191. Feng Z, Li L, Wang Q, Wu G, Liu C, Jiang B, Xu J (2019) Effect of antioxidant and antimicrobial coating based on whey protein nanofibrils with $\mathrm{TiO} 2$ nanotubes on the quality and shelf life of chilled meat. Int J Mol Sci 20:1184

192. Fernández-Pan I, Carrión-Granda X, Maté JI (2014) Antimicrobial efficiency of edible coatings on the preservation of chicken breast fillets. Food Control 36:69-75

193. Bazargani-Gilani B, Aliakbarlu J, Tajik H (2015) Effect of pomegranate juice dipping and chitosan coating enriched with Zataria multiflora Boiss essential oil on the shelf-life of chicken meat during refrigerated storage. Innov Food Sci Emerg Technol 29: 280-287

194. Ruan C, Zhang Y, Sun Y, Gao X, Xiong G, Liang J (2019) Effect of sodium alginate and carboxymethyl cellulose edible coating with epigallocatechin gallate on quality and shelf life of fresh pork. Int J Biol Macromol 141:178-184

195. Sharaf Eddin A, Ibrahim SA, Tahergorabi R (2019) Egg quality and safety with an overview of edible coating application for egg preservation. Food Chem 296:29-39

196. Dávalos-Saucedo CA, Rossi-Márquez G, Regalado-González C, Alonzo-Macías M, Di Pierro P (2018) Application of transglutaminase crosslinked whey protein-pectin coating improves egg quality and minimizes the breakage and porosity of eggshells. Coatings 8(12):438

197. Angiolillo L, Conte A, Faccia M, Zambrini AV, Del Nobile MA (2014) A new method to produce synbiotic Fiordilatte cheese. Innov Food Sci Emerg Technol 22:180-187

198. Göksen G, Fabra MJ, Ekiz HI, López-Rubio A (2020) Phytochemical-loaded electrospun nanofibers as novel active edible films: characterization and antibacterial efficiency in cheese slices. Food Control 112:107133

199. Saravani M, Ehsani A, Aliakbarlu J, Ghasempour Z (2019) Gouda cheese spoilage prevention: biodegradable coating induced by Bunium persicum essential oil and lactoperoxidase system. Food Sci Nutr 7:959-968

200. Civelek I, Cagri-Mehmetoglu A (2019) Determination of antifungal effect of edible coatings containing Williopsis saturnus var. saturnus against yeast and mold growth on kashar cheese. J. Food Sci 84:311-318

201. Ortiz de Elguea-Culebras G, Bourbon AI, Costa MJ, MuñozTebar N, Carmona M, Molina A, Sánchez-Vioque R, Berruga MI, Vicente AA (2019) Optimization of a chitosan solution as potential carrier for the incorporation of Santolina chamaecyparissus L. solid by-product in an edible vegetal coating on 'Manchego' cheese. Food Hydrocoll 89:272-282

202. Zhu D, Guo R, Li W, Song J, Cheng F (2019) Improved postharvest preservation effects of Pholiota nameko mushroom by sodium alginate-based edible composite coating. Food Bioprocess Technol 12:587-598
203. Grosso AL, Asensio CM, Grosso NR, Nepote V (2020) Increase of walnuts' shelf life using a walnut flour protein-based edible coating. LWT 118:108712

204. Gómez-López VM, Ragaert P, Debevere J, Devlieghere F (2007) Pulsed light for food decontamination: a review. Trends Food Sci Technol 18:464-473

205. Mahendran R, Ramanan KR, Barba FJ, Lorenzo JM, LópezFernández O, Munekata PES, Roohinejad S, Sant'Ana AS, Tiwari BK (2019) Recent advances in the application of pulsed light processing for improving food safety and increasing shelf life. Trends Food Sci Technol 88:67-79

206. Gouma M, Condón S, Mañas P, Álvarez I, Gayán E (2016) The use of UV light for food preservation: an overview. In: Lyng I, EGP and J (Eds) Intensity pulsed light in processing. pp 767-776 ISBN 9781634848329

207. Jean J, Morales-Rayas R, Anoman MN, Lamhoujeb S (2011) Inactivation of hepatitis A virus and norovirus surrogate in suspension and on food-contact surfaces using pulsed UV light (pulsed light inactivation of food-borne viruses). Food Microbiol 28:568-572

208. Pataro G, Muñoz A, Palgan I, Noci F, Ferrari G, Lyng JG (2011) Bacterial inactivation in fruit juices using a continuous flow pulsed light (PL) system. Food Res Int 44:1642-1648

209. Chen BY, Lung HM, Yang BB, Wang CY (2015) Pulsed light sterilization of packaging materials. Food Packag Shelf Life 5:1-9

210. Wang T, MacGregor SJ, Anderson JG, Woolsey GA (2005) Pulsed ultra-violet inactivation spectrum of Escherichia coli. Water Res 39:2921-2925

211. Wekhof A (2000) Disinfection with flash lamps. PDA J Pharm Sci Technol 54:264-276

212. Wekhof A, Trompeter F-J, Franken O (2001) Pulsed UV disintegration (PUVD): a new sterilisation mechanism for packaging and broad medical-hospital applications. In: Proceedings of the The first international conference on ultraviolet technologies, June14-16, 2001, Washington D.C. (U.S.), pp 1-15

213. Takeshita K, Shibato J, Sameshima T, Fukunaga S, Isobe S, Arihara K, Itoh M (2003) Damage of yeast cells induced by pulsed light irradiation. Int J Food Microbiol 85:151-158

214. Krishnamurthy K, Tewari JC, Irudayaraj J, Demirci A (2010) Microscopic and spectroscopic evaluation of inactivation of staphylococcus aureus by pulsed UV light and infrared heating. Food Bioprocess Technol 3:93-104

215. Gómez-López VM, Bolton JR (2016) An approach to standardize methods for fluence determination in bench-scale pulsed light experiments. Food Bioprocess Technol 9:1040-1048

216. Pataro G, Sinik M, Capitoli MM, Donsì G, Ferrari G (2015) The influence of post-harvest UV-C and pulsed light treatments on quality and antioxidant properties of tomato fruits during storage. Innov Food Sci Emerg Technol 30:103-111

217. Ramos-Villarroel AY, Aron-Maftei N, Martín-Belloso O, SolivaFortuny R (2012) Influence of spectral distribution on bacterial inactivation and quality changes of fresh-cut watermelon treated with intense light pulses. Postharvest Biol Technol 69:32-39

218. Manzocco L, Nicoli MC, Scampicchio M (2017) Effects of ascorbic acid and light on reactions in fresh-cut apples by microcalorimetry. Thermochim Acta 649:63-68

219. Krishnamurthy K, Demirci A, Irudayaraj JM (2007) Inactivation of Staphylococcus aureus in milk using flow-through pulsed UVlight treatment system. J Food Sci 72(7):M233-M239

220. Ferrario M, Guerrero S (2016) Effect of a continuous flowthrough pulsed light system combined with ultrasound on microbial survivability, color and sensory shelf life of apple juice. Innov Food Sci Emerg Technol 34:214-224

221. Artíguez ML (2015) Martínez de Marañón, I. Improved process for decontamination of whey by a continuous flow-through pulsed light system. Food Control 47:599-605 
222. Gómez-López VM, Devlieghere F, Bonduelle V, Debevere J (2005) Factors affecting the inactivation of micro-organisms by intense light pulses. J Appl Microbiol 99:460-470

223. Pataro G, De Maria S, Lyng JG (2016) Factors determining the efficacy of a pulsed light treatment. In: Pataro G, Lyng JG (eds) High intensity pulsed light in processing and preservation of foods. Nova Science Publishers, Inc., pp 85-108

224. Hsu L, Moraru CI (2011) Quantifying and mapping the spatial distribution of fluence inside a pulsed light treatment chamber and various liquid substrates. J Food Eng 103:84-91

225. Rowan NJ, Gregor SJMAC, Anderson JG, Fouracre RA, Ilvaney LMC (1999) Pulsed-light inactivation of food-related microorganisms. 65:1312-1315

226. Levy C, Aubert X, Lacour B, Carlin F (2012) Relevant factors affecting microbial surface decontamination by pulsed light. Int $\mathrm{J}$ Food Microbiol 152:168-174

227. Woodling SE, Moraru CI (2007) Effect of spectral range in surface inactivation of Listeria innocua using broad-spectrum pulsed light. J Food Prot 70:909-916

228. Keklik NM, Krishnamurthy K, Demirci A (2012) Microbial decontamination of food by ultraviolet (UV) and pulsed UV light. In: Demirci A, Ngadi M (eds) Microbial decontamination in the food industry. Novel methods and applications. Woodhead Publishing, pp 344-369. https://doi.org/10.1533/9780857095756.2.344

229. Woodling SE, Moraru CI (2005) Influence of surface topography on the effectiveness of pulsed light treatment for the inactivation of Listeria innocua on stainless-steel surfaces. J Food Sci 70:m345m351

230. Ringus DL, Moraru CI (2013) Pulsed light inactivation of Listeria innocua on food packaging materials of different surface roughness and reflectivity. J Food Eng 114:331-337

231. Hoover DG (2000) Suppement kinetics of microbial inactivation for alternative food processing technologies.

232. Uesugi AR, Woodling SE, Moraru CI (2007) Inactivation kinetics and factors of variability in the pulsed light treatment of Listeria innocua cells. J Food Prot 70:2518-2525

233. U.S. FDA irradiation in the production, processing and handling of food. In CFR - Code of Federal Regulations Title 21, Volume 3, Part 179; 2019; p. 21CFR179.41

234. Bialka KL, Demirci A (2008) Efficacy of pulsed UV-light for the decontamination of Escherichia coli O157:H7 and Salmonella spp. on raspberries and strawberries. J Food Sci 73(5):M201M207

235. Aguiló-Aguayo I, Charles F, Renard CMGC, Page D, Carlin F (2013) Pulsed light effects on surface decontamination, physical qualities and nutritional composition of tomato fruit. Postharvest Biol Technol 86:29-36

236. John D, Ramaswamy HS (2018) Pulsed light technology to enhance food safety and quality: a mini-review. Curr Opin Food Sci 23:70-79

237. Ribeiro C, Canada J, Alvarenga B (2012) Prospects of UV radiation for application in postharvest technology. Emirates J Food Agric 24:586-597

238. Urban L, Chabane Sari D, Orsal B, Lopes M, Miranda R, Aarrouf J (2018) UV-C light and pulsed light as alternatives to chemical and biological elicitors for stimulating plant natural defenses against fungal diseases. Sci Hortic (Amsterdam) 235:452-459

239. Pataro G, Donsi G, Ferrari G (2015) Post-harvest UV-C and PL irradiation of fruits and vegetables. Chem Eng Trans 44:31-36

240. Rodov V, Vinokur Y, Horev B (2012) Brief postharvest exposure to pulsed light stimulates coloration and anthocyanin accumulation in fig fruit (Ficus carica L.). Postharvest Biol Technol 68:4346

241. Denoya GI, Pataro G, Ferrari G (2020) Effects of postharvest pulsed light treatments on the quality and antioxidant properties of persimmons during storage. Postharvest Biol Technol 160: 111055

242. Koyyalamudi SR, Jeong SC, Pang G, Teal A, Biggs T (2011) Concentration of vitamin D2 in white button mushrooms (Agaricus bisporus) exposed to pulsed UV light. J Food Compos Anal 24:976-979

243. Xenon food safety and enhancement with pulsed UV light Available online: https://xenoncorp.com/food-safety/other-foodapplications/. Accessed 16 Apr 2020

244. Lado BH, Yousef AE (2002) Alternative food-preservation technologies: efficacy and mechanisms. Microbes Infect 4:433-440

245. Zhang ZH, Wang LH, Zeng XA, Han Z, Brennan CS (2019) Nonthermal technologies and its current and future application in the food industry: a review. Int J Food Sci Technol 54:1-13

246. Ansorena MR, Ponce AG (2019) Coatings in the postharvest. In: Gutiérrez T (ed) Polymers for agri-food applications. Springer International Publishing, Cham, pp 339-354. https://doi.org/10. 1007/978-3-030-19416-1_17

247. Brecht JK, Saltveit ME, Talcott ST, Schneider KR, Felkey K, Bartz JA (2010) Fresh-cut vegetables and fruits. In: Horticultural reviews. Wiley, Oxford, pp 185-251

248. Gutiérrez TJ (2017) Effects of exposure to pulsed light on molecular aspects of edible films made from cassava and taro starch. Innov Food Sci Emerg Technol 41:387-396

249. Bertuzzi MA, Castro Vidaurre EF, Armada M, Gottifredi JC (2007) Water vapor permeability of edible starch based films. J Food Eng 80:972-978

250. García-Tejeda YV, López-González C, Pérez-Orozco JP, RendónVillalobos R, Jiménez-Pérez A, Flores-Huicochea E, SolorzaFeria J, Bastida CA (2013) Physicochemical and mechanical properties of extruded laminates from native and oxidized banana starch during storage. LWT Food Sci Technol 54:447-455

251. Gutiérrez TJ, González G (2016) Effects of exposure to pulsed light on surface and structural properties of edible films made from cassava and taro starch. Food Bioprocess Technol 9:1812-1824

252. Wihodo M, Moraru CI (2015) Effect of pulsed light treatment on the functional properties of casein films. LWT Food Sci Technol 64:837-844

253. de Moraes JO, Hilton ST, Moraru CI (2020) The effect of pulsed light and starch films with antimicrobials on Listeria innocua and the quality of sliced cheddar cheese during refrigerated storage. Food Control 112:107134

254. Heinrich V, Zunabovic M, Bergmair J, Kneifel W, Jäger H (2015) Post-packaging application of pulsed light for microbial decontamination of solid foods: a review. Innov Food Sci Emerg Technol 30:145-156

255. Guillard V, Mauricio-Iglesias M, Gontard N (2010) Effect of novel food processing methods on packaging: structure, composition, and migration properties. Crit Rev Food Sci Nutr 50:969-988

256. Keklik NM, Demirci A, Puri VM (2009) Inactivation of listeria monocytogenes on unpackaged and vacuum-packaged chicken frankfurters using pulsed UV-light. J Food Sci 74:M431-M439

257. Pospíšil J, Nešpůrek S (2008) Polymer additives. ISBN 9783527314553.

258. Fernández M, Manzano S, De La Hoz L, Ordóñez JA, Hierro E (2009) Pulsed light inactivation of Listeria monocytogenes through different plastic films. Foodborne Pathog Dis 6:12651267

259. Keklik NM, Demirci A, Puri VM (2010) Decontamination of unpackaged and vacuum-packaged boneless chicken breast with pulsed ultraviolet light. Poult Sci 89:570-581

260. Haughton PN, Lyng JG, Morgan DJ, Cronin DA, Fanning S, Whyte P (2011) Efficacy of high-intensity pulsed light for the microbiological decontamination of chicken, associated packaging, and contact surfaces. Foodborne Pathog Dis 8:109-117 
261. Rojas-Graü MA, Tapia MS, Rodríguez FJ, Carmona AJ, MartinBelloso O (2007) Alginate and gellan-based edible coatings as carriers of antibrowning agents applied on fresh-cut Fuji apples. Food Hydrocoll 21:118-127

262. Moreira MR, Tomadoni B, Martín-Belloso O, Soliva-Fortuny R (2015) Preservation of fresh-cut apple quality attributes by pulsed light in combination with gellan gum-based prebiotic edible coatings. LWT 64:1130-1137

263. Moreira MR, Álvarez MV, Martín-Belloso O, Soliva-Fortuny R (2016) Effects of pulsed light treatments and pectin edible coatings on the quality of fresh-cut apples: a hurdle technology approach. J Sci Food Agric 97:261-268

264. Salinas-Roca B, Soliva-Fortunay R, Welti-Chanes J, MartìnBelloso O (2016) Combined effect of pulsed light, edible coating and malic acid dipping to improve fresh-cut mango safety and quality. Food Control 66:190-197

265. Koh PC, Noranizan MA, Hanani ZAN, Karim R, Rosli SZ (2017) Application of edible coatings and repetitive pulsed light far shelf life extension of fresh-cut cantaloupe (Cucumis melo L. reticulatus cv. Glamour). Postharvest Biol Technol 129:64-78
266. Salinas-Roca B, Soliva-Fortuny R, Welti-Chanes J, MartínBelloso O (2017) Effect of pulsed light, edible coating, and dipping on the phenolic profile and antioxidant potential of fresh-cut mango. J Food Process Preserv 42:1-9

267. Taștan Ö, Pataro G, Donsì F, Ferrari G, Baysal T (2017) Decontamination of fresh-cut cucumber slices by a combination of a modified chitosan coating containing carvacrol nanoemulsions and pulsed light. Int J Food Microbiol 260:75-80

268. Koh PC, Noranizan MA, Karim R, Nur Hanani ZA, Lasik-Kurdyś $M$ (2018) Combination of alginate coating and repetitive pulsed light for shelf life extension of fresh-cut cantaloupe (Cucumis melo L. reticulatus cv. Glamour). J Food Process Preserv 42:1-18

269. Koh PC, Noranizan MA, Karim R, Nur Hanani ZA, Rosli SZ, Hambali NH (2019) Enzymatic activity of alginate coated and pulsed light treated fresh-cut cantaloupes (Cucumis melo L. var. reticulatus cv. Glamour) during chilled storage. Int Food Res J 26: $547-556$

Publisher's Note Springer Nature remains neutral with regard to jurisdictional claims in published maps and institutional affiliations. 